\title{
ASPECTOS ECOLÓGICOS E GENÉTICOS DE UMA POPULAÇÃO NATURAL DE Euterpe oleracea Mart. NO ESTUÁRIO AMAZÔNICO
}

\author{
PATRÍCIA CRISTINA AMORIM DE SOUZA \\ Engenheiro Florestal
}

Orientador: Prof. Dr. PAULO YOSHIO KAGEYAMA

Dissertação apresentada à Escola Superior de Agricultura "Luiz de Queiroz", Universidade de São Paulo, para obtenção do título de Mestre em Recursos Florestais, com opção em Conservação de Ecossistemas Florestais.

PIRACICABA

Estado de São Paulo - Brasil

Abril - 2002 


\section{Dados Internacionais de Catalogação na Publicação (CIP) DIVISÃO DE BIBLIOTECA E DOCUMENTAÇÃO - ESALQ/USP}

Souza, Patrícia Cristina Amorim de

Aspectos ecológicos e genéticos de uma população natural de Euterpe oleracea

Mart. no estuário amazônico / Patricia Cristina Amorim de Souza. - - Piracicaba, 2002.

$60 \mathrm{p}$.

Dissertação (mestrado) - - Escola Superior de Agricultura Luiz de Queiroz, 2002. Bibliografia.

1. Açaí 2. Ecologia florestal 3. Genética de populações 4. Manejo florestal 5. Palmeira oleaginosa 6. Variação genética em plantas I. Título

CDD 633.851

Sermitida a cón total ou parcha deste doemento, desde que citah a fonte - 0 autor? 


\section{PROBLEMAS}

"Tu podes resolver problemas.

A tua força flui de acordo com a intensidade da tua convicção.

Pensa ser capaz de resolver os problemas, e te sentirás bem.

Nem toda situação é problema. Problema é o que resulta da tua apreciação e consideração. Se te julgas sem força ou inteligência para resolver o que tens à frente, isso se torna problema, dificuldade, entrave. Afirma-te com qualidades, e vence os problemas. Fala firmemente:

Sou forte, tenho saúde, tenho beleza, Tenho bondade, nada me falta.

Depois, vai em frente. Luta, trabalha, Vibra, ama. Nunca desanimes.

O problema não é nada para quem sabe que tem as chaves da solução dentro de si".

(Lourival Lopes, ÂNIMO)

\section{OFEREÇO}

A valiosa Família que tenho, responsável pela minha formação e determinação! E ao "Preto Velho". com todo o meu amor, carinho e admiração! 


\section{AGRADECIMENTOS}

Agradeço a todos que possibilitaram a realização deste trabalho e de um sonho...

Ao Prof. Dr. Paulo Yoshio Kageyama, pela orientação e oportunidade de aprendizado na área da Genética.

Ao Prof. Luiz Gonzaga da Silva Costa, pela minha iniciação na pesquisa durante a graduação e pelo incentivo e amizade.

À Fernanda Gaiotto, pelos ensinamentos de Laboratório, mundo até então desconhecido e pela atenção e dedicação dispensada.

Ao Flávio Gandara, pelas sugestões na elaboração do projeto e conversas informais no laboratório.

Ao Luciano, pela correção da tese contribuindo em muito para o resultado final.

Ao LARGEA (Elza, Gelson, Andréia, Maria e Glauce) pela colaboração e ajuda.

À Estação Científica Ferreira Penna, Museu Paraense Emílio Goeldi pela oportunidade de realização deste trabalho na FLONA de Caxiuanã ("lugar de muitas cobras").

Aos companheiros de campo: Seu Dico (Identificador botânico), Quenevaldo e Mó, pela super ajuda na coleta dos dados.

Aos professores da Faculdade de Ciências Agrárias do Pará, pelas sugestões e apoio sempre que procurados.

Aos amigos de Laboratório pelo incentivo, amizade e companheirismo (Karina, Sybelle, Luciano, Nivaldo, Dôdô, Helena, Flávio, Cipó, João, Fernanda e Thaís).

À grande amiga e afilhada Veridiana (Pêra), que compartilhou comigo todos os bons e não bons momentos, desde as primeiras horas que cheguei em Piracicaba.

Aos amigos de "longe", Elisana, Keila e Marlon que torceram pela realização deste trabalho, mesmo a distância.

Aos amigos de "perto", colônia paraense, paulistas, mineiros, capixabas e baianos, pela amizade e força. 
Ao Hudson, por participar ativamente deste trabalho, durante estes dois anos, e principalmente pelo apoio, dedicação, carinho e amor.

Aos meus pais, Carlos e Iracely, principais responsáveis pela realização de mais esta etapa da minha vida Aos meus irmãos maravilhosos Victor e Vinicius que ficaram torcendo pela "morena" deles. À vocês quatro agradeço pela presença constante, amor e palavras de apoio, força e incentivo, como estas:

"Mana, não esqueça que nós lembramos de você à cada minuto, aqui em Belém. Continue nesta sua caminhada, que é de muito progresso e orgulho para todos nós. Confie na sua força interior. Ela nunca te abandonará. Que Deus te abençoe". (Victor Felipe, julho 2000)

Deus, obrigada pala oportunidade da vida e pela realização deste trabalho! 


\section{SUMÁRIO}

Página

RESUMO.

viii

SUMMARY

$\mathrm{X}$

1 INTRODUÇÃO

2 REVISÃO DE LITERATURA........................................................................ 4

2.1 Caracterização da Espécie Euterpe oleracea Mart.................................................. 4

2.1.1 Aspectos botânicos...................................................................................... 4

2.1.2 Potencial socioeconômico e manejo do açaizeiro................................................. 6

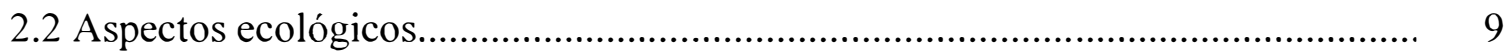

2.2.1 Estrutura de população...................................................................................... 9

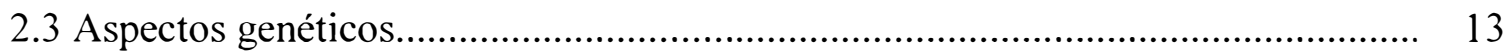

2.3.1 Variabilidade genética em populações naturais................................................ 13

2.3.2 Taxa de cruzamento e fluxo gênico................................................................. 15

2.3.2 Marcador molecular microssatélite ................................................................. 17

3 MATERIAL E MÉTODOS..................................................................... 19

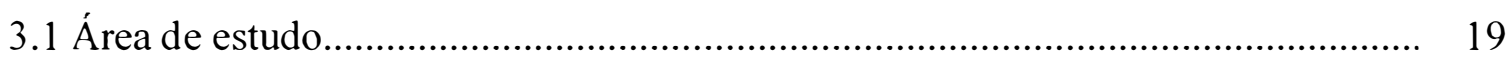

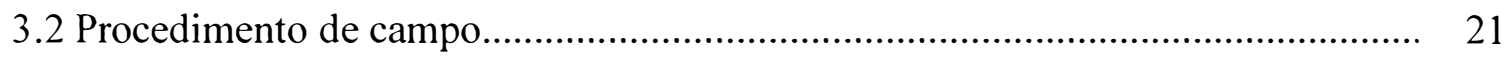

3.2.1 Levantamento da população............................................................................. 21

3.2.2 Coleta do material botânico.......................................................................... 23

3.3 Protocolo de laboratório.................................................................................. 23

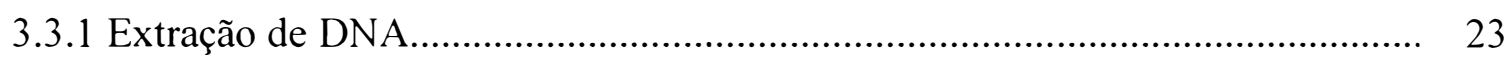

3.3.2 Obtenção de marcadores microssatélites.......................................................... 25

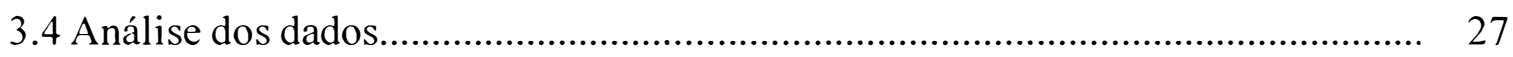

3.4.1 Caracterização dos estádios ontogenéticos........................................................ 27

3.4.2 Estrutura de tamanho da população................................................................. 28 
3.4.3 Distribuição espacial da população................................................................. 29

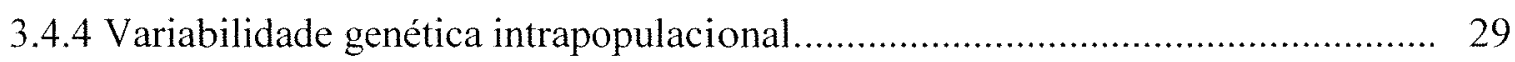

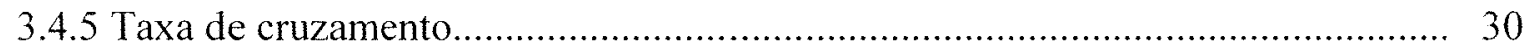

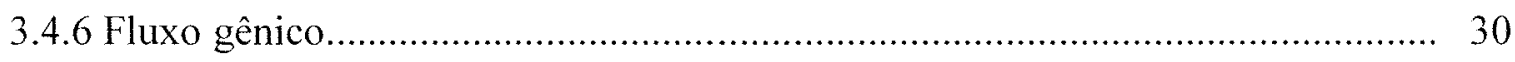

4 RESULTADOS E DISCUSSÃO.................................................................... 31

4.1 Caracterização dos estádios ontogenéticos......................................................... 31

4.2 Estrutura de população................................................................................... 38

4.3 Variabilidade genética................................................................................ 42

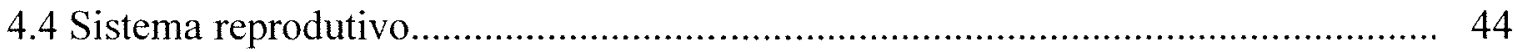

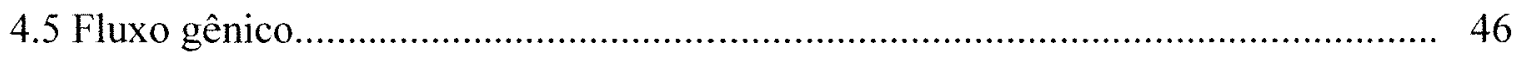

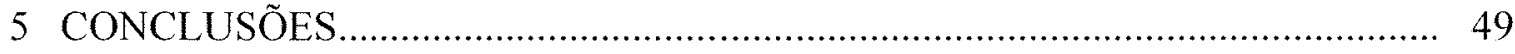

REFERÊNCIAS BIBLIOGRÁFICAS.............................................................. 50 


\title{
ASPECTOS ECOLÓGICOS E GENÉTICOS DE UMA POPULAÇÃO NATURAL DE Euterpe oleracea Mart. NO ESTUÁRIO AMAZÔNICO
}

\author{
Autora: PATRÍCIA CRISTINA AMORIM DE SOUZA \\ Orientador: Prof. Dr. PAULO YOSHIO KAGEYAMA
}

\section{RESUMO}

Este estudo teve como principal objetivo conhecer a ecologia e genética de uma população natural de Euterpe oleracea Mart.(açaizeiro), visando gerar informações que possibilitem definir parâmetros e critérios para subsidiar planos de manejo florestal sustentável de açaizais. O conhecimento ecológico-genético das espécies arbóreas nativas tem grande importância para o uso dos recursos florestais e a manutenção da biodiversidade da floresta tropical. O açaizeiro é uma espécie clímax abundante no subdossel das florestas de várzea, encontrada em todo o estuário amazônico, apresenta alta importância econômica em função da viabilidade de exploração contínua, através do manejo adequado de seus perfilhos. Nesse contexto, torna-se fundamental o estudo da estrutura populacional, diversidade genética e fluxo gênico desta espécie, o qual poderá ser modelo para outras espécies similares da Floresta Tropical. Foi implantada uma parcela amostral de 1 ha, em uma população representativa da espécie no Município de Melgaço-PA; os parâmetros genéticos populacionais foram estudados com o auxílio de cinco locos microssatélites. A população de E.oleracea apresentou uma estrutura de tamanho do tipo $\mathrm{J}$ invertido, os estádios ontogenéticos caracterizados para plantas e touceiras (Jovem, Imaturo I, Imaturo II e Adulto) apresentaram um padrão de distribuição aleatório, com exceção do estádio de Plântula que apresentou um padrão agrupado. A diversidade alélica média $(H e)$ e a heterozigosidade observada $(\mathrm{Ho})$ 
apresentaram valores elevados para adultos 0,839 e 0,709, respectivamente. As plântulas também apresentaram valores elevados, 0,844 e 0,822 , respectivamente. A caracterização da taxa de cruzamento $(t m=1)$ para a população estudada indica a alogamia como mecanismo básico de reprodução da espécie, com elevada probabilidade de gerarem irmãos germanos dentro de famílias de polinização aberta ( $r p$ de 0,594$)$. Entretanto, a diferença entre a taxa de cruzamento multilocos e unilocos (tm-ts igual a $0,129)$ também mostram cruzamento entre indivíduos aparentados. À distância do fluxo gênico direto variou de $6,20 \mathrm{~m}$ a $76,78 \mathrm{~m}$. Portanto, como apenas $9,8 \%$ das progênies tiveram seus possíveis pais determinados, podemos considerar a existência de fecundação por pólen de indivíduos não amostrados e admitir que o fluxo gênico via pólen seja mais amplo do que foi detectado neste estudo. Com base nestes resultados é possível que sejam direcionadas práticas de manejo para o açaizeiro, que visem a conservação e utilização dos recursos genéticos da espécie de forma sustentável. 


\title{
ECOLOGICAL AND GENETIC ASPECTS OF A NATURAL POPULATION OF Euterpe oleracea Mart. IN THE AMAZON ESTUARY
}

\author{
Author: PATRÍCIA CRISTINA AMORIM DE SOUZA \\ Adviser: Prof. Dr. PAULO YOSHIO KAGEYAMA
}

\section{SUMMARY}

The goal of this study was to know the ecology and genetics of a natural population of Euterpe oleracea Mart. (açai palm) in order to generate information allowing the definition of parameters and criteria to subsidize sustainable forest management plans of the açai palm. The ecological-genetic knowledge of native tree species is very important to the use of forest resources and to the maintenance of the tropical forest biodiversity. The açai palm is an abundant climax species at the subcanopy of bottomland forests, found throughout the Amazon estuary; it is highly important economically in view of the viability of continuous exploitation, through an adequate management of its sprouts. In that sense, the study of the populational structure, genetic diversity and gene flow of this species is fundamental, and may become a model to other similar species of the Tropical Forest. A 1-ha sample plot was set up in a representative population of the species in the municipality of Melgaço-PA; populational genetic parameters were studied with the aid of five microsatellite loci. The population of E.oleracea presented an inverted-J type size structure; the ontogenetic stages characterized for plants and stools (Yung, Immature I, Immature II, and Adult) had a random distribution pattern, except for the Seedlings, which had a clustered pattern. The mean allelic diversity $(\mathrm{He})$ and the observed heterozigosity $(\mathrm{Ho})$ showed high values for adults ( 0.839 and 0.709 , respectively.). Also the seedlings showed high 
levels $(0.844$ and 0.822 , respectively). The characterization of the outcrossing rate $(\mathrm{tm}=$ 1) for the studied population indicates allogamy as a basic mechanism of species reproduction with a high probability to generate sibs within open pollination families ( $r p$ 0.594). However, the difference between the multiloci and single loci outcrossing rate (tm- $t s$ 0.129) also points a cross among parenting individuals. The distance of the direct gene flow varied from $6.20 \mathrm{~m}$ to $76.78 \mathrm{~m}$. Therefore, since only $9.8 \%$ of the progenies had their possible parents determined, the fertilization by pollen of non-sampled individuals can be taken into account and the gene flow via pollen can be assumed to be broader than what was detected in this study. Based on these results, management practices are likely to be directed to the açai palm viewing the conservation and use of the genetic resources of the species in a sustainable way. 


\section{INTRODUÇÃO}

A floresta tropical cobre menos que 7\% da superfície terrestre. Em 1990, existiam 1.756 milhões de ha de florestas tropicais naturais, sendo que 52\% da área estava localizada nas Américas (FAO, 1993). Apesar de suas características únicas de diversidade e endemismo, mais de $1 \%$ do bioma das florestas tropicais está sendo desmatado e mais de 1\% está sendo degradado por ano (Myers, 1988).

A Floresta Atlântica e a Amazônia são dois biomas de floresta tropical do Brasil, responsáveis pela maior diversidade arbórea do mundo. Esta última com possibilidades concretas de tornar possível a conservação dos recursos naturais com o desenvolvimento sócio-econômico da região. Isto se deve ao fato da Amazônia apresentar ainda $85 \%$ dos seus 350 milhões de ha de cobertura florestal original em pé. No caso da Mata Atlântica, esta possibilidade é mais restrita, visto que, dos 100 milhões de ha de floresta original, restam menos que $10 \%$ da cobertura vegetal original.

Deste modo, para um ecossistema com alta diversidade de espécies como a floresta tropical, o desenvolvimento de estudos com uma espécie clímax comum no subdossel do estuário amazônico - Euterpe oleracea Mart. (açaizeiro) - é importante para aumentar os conhecimentos básicos desse tipo de ecossistema. Além disso, o fato do açaizeiro apresentar perfilhamento e frutificar durante todo o ano, com alguns picos de produtividade (Jardim, 1991), lhe confere um papel importante na manutenção da fauna, funcionando como nutridor de grande quantidade de animais silvestres; sendo assim, uma espécie estratégica no equilíbrio e na dinâmica do ecossistema onde é predominante.

A Amazônia é composta por formações vegetais floristicamente distintas. Dentre elas, está a floresta de terra-firme que corresponde a $90 \%$ da formação florestal amazônica (Pires, 1972), e as de várzea e igapó, que apesar de estarem representadas em menor escala em termos de área, são de grande importância, tanto no sentido de 
manutenção dos rios, quanto em termos econômicos e principalmente sociais (Ohashi, 1990).

O açaizeiro é uma espécie de fundamental importância para as comunidades ribeirinhas da Amazônia, principalmente do estuário, por ser alimento básico da dieta dessas comunidades, fazendo parte da sua cultura e sendo hoje uma das principais fontes de renda com a produção do suco do açaí. Forma populações densas, quase homogêneas na Região do Estuário Amazônico, principalmente nas áreas de várzea e igapó (Calzavara, 1972).

A viabilidade de exploração contínua do açaizeiro, por meio da colheita de frutos e palmito, e a grande abundância de individuos, que se apresentam em perfilhos de diferentes estádios de desenvolvimento dentro das florestas, possibilita a implantação de um sistema de manejo sustentável para as populações naturais. Sobretudo, para que o manejo seja realizado sob uma ótica conservacionista, é necessário estabelecer ações que visem a manutenção da dinâmica demográfica e estrutura genética das populações naturais, além de assegurar as interações com as demais espécies do ecossistema (Reis et al., 1994).

No entanto, populações naturais estão sendo exploradas de forma predatória, sendo que, freqüentemente, é realizada a extração do palmito através do corte raso de extensas áreas de açaizais. Este procedimento retarda a regeneração, impossibilita a colheita simultânea de frutos (Jardim \& Anderson, 1987) e restringe a diversidade genética da espécie pela fragmentação das populações.

São raros os casos de espécies estudadas do ponto de vista ecológico e genético. Segundo Oyama (1993), tais informações são cruciais para possíveis intervenções em espécies sob manejo, tanto no processo de conservação quanto de produção. As principais ferramentas desses estudos consistem no conhecimento do sistema reprodutivo, do fluxo gênico intra e interpopulacional, na distribuição espacial dos indivíduos e, principalmente, na distribuição da variação genética entre e dentro de populações das espécies florestais (Kageyama, 1987).

Marcadores moleculares baseados em Seqüências Simples Repetitivas (SSR), ou microssatélites, tem sido usados em estudos de populações naturais, principalmente na 
determinação de sistema de cruzamento, fluxo gênico e estrutura genética populacional (Chase et al., 1996; Gaiotto, 2001). Tais marcadores são considerados ideais para estes tipos de estudos por serem codominantes, altamente polimórficos, multialélicos e amplamente distribuído por todo o genoma (Rafalski et al.,1996).

Assim, a partir da quantificação da variabilidade genética dentro da população de E. oleracea, utilizando marcador molecular microssatélite, serão obtidas informações importantes, até então, deficientes em planos de manejo florestal da espécie, as quais permitirão planejar o manejo com menor perda de diversidade genética para a espécie.

Outra informação importante, é a determinação do fluxo gênico intrapopulacional, possibilitando detectar a distância mínima entre indivíduos aparentados. Baseando-se neste conhecimento, o manejo sustentável poderá prevenir cruzamentos endogâmicos, os quais levariam à erosão genética das populações ou até mesmo à extinção local da espécie.

Diante do exposto este trabalho visa gerar informações que possibilitem definir parâmetros e critérios para subsidiar planos de manejo florestal sustentável de açaizais, além de fundamentar medidas de conservação por meio do estudo de aspectos da ecologia e genética de uma população natural da palmeira Euterpe oleracea Mart. na Estação Científica "Ferreira Penna"- ECFPn, Município de Melgaço-PA.

Sendo assim, os principais objetivos deste trabalho são:

1) Classificar em estádios ontogenéticos a população de E. oleracea estudada;

2) Caracterizar a estrutura de tamanho apresentada pela população de E. oleracea;

3) Determinar o padrão de distribuição espacial dos estádios na população de $E$. oleracea;

4) Quantificar a variabilidade genética intrapopulacional utilizando marcadores microssatélites;

5) Estimar a taxa de cruzamento da espécie na população;

6) Detectar o fluxo gênico intrapopulacional, através de testes de paternidade. 


\section{REVISÃO DE LITERATURA}

\subsection{Caracterização da espécie Euterpe oleracea Mart.}

\subsubsection{Aspectos botânicos}

O açaizeiro (Euterpe oleracea Mart.), pertence à divisão Magnoliophyta (Angiospermae), classe Liliopsida, subclasse Arecidae, superordem Arecanae, ordem Arecales, família Arecacea, subfamília Arecoidae, gênero Euterpe e espécie oleracea. É uma palmeira tipicamente tropical nativa da Amazônia Oriental, de porte esguio, fazendo parte da composição florística das áreas de várzea, terra firme e igapó (Calzavara, 1972). O mesmo autor relata que a espécie ocorre nos estados do Amazonas, Maranhão, Amapá e Pará (estendendo-se pelo Estuário Amazônico), chegando nas Guianas e Venezuela.

A espécie Euterpe oleracea é uma palmeira que possui ramificação basal (Hallé et al., 1978), o que permite a formação de vários estipes por indivíduo (Jardim \& Anderson, 1987), num conjunto conhecido como touceira. Logo, todos os estipes de uma mesma touceira apresentam o mesmo genótipo, ou seja, geneticamente uma touceira constitui-se em um indivíduo.

As touceiras podem ser formadas por até mais de 20 estipes (Moreira, 1998), em diferentes estádios de crescimento; produzindo de 3 a 4 cachos por cada estipe, também em estádios fenológicos distintos (Cavalcante, 1991). O perfilhamento geralmente ocorre a partir do terceiro ano de idade da planta-mãe, a partir do qual, possibilita a exploração sustentável da espécie (Jardim, 1995) por não ocasionar a morte da planta com a retirada de um ou mais estipes por touceira. 
Segundo Nogueira (1997) e Moreira (1998), o sistema radicular do açaizeiro é do tipo fasciculado ou em cabeleira, bastante denso e superficial, com as raízes emergindo da base do estipe independentemente da idade das plantas.

O caule é denominado de estipe sendo cilíndrico, anelado e sem ramificações, de cor gris claro, podendo alcançar até $35 \mathrm{~m}$ de comprimento, com um diâmetro de 12 a 18 $\mathrm{cm}$ na idade adulta (Rogez, 2000). As folhas são pinadas e em número de 10 a 12 por estipe, alcançando até $2 \mathrm{~m}$ de comprimento, compostas de 70 a 80 pares de folíolos, desprendendo-se totalmente do fuste quando envelhecem e secam (Nogueira, 1997). As folhas geralmente são usadas para forrar casas e na confecção de artesanatos, além de utilizadas na alimentação do gado (Cavalcante, 1991).

Segundo Rogez (2000), nas axilas das folhas nascem inflorescências solitárias chamadas de espádices (cachos), estes desenvolvem-se após a queda das folhas.

A inflorescência é envolvida pela espatela e espata que são brácteas desiguais de consistência coriáceas ou membranosas, as quais protegem as flores antes da antese. A inflorescência é formada por um eixo central de ráquis e por vários eixos secundários as ráquilas, onde estão dispostas flores unissexuais, sésseis, em tríades, sendo a central feminina (Calzavara, 1987). Estas são visitadas por vários insetos, porém insetos da ordem Coleoptera são os principais polinizadores (Jardim, 1995).

Ao atingir a idade de 3,5 a 4 anos, o açaizeiro entra em início de floração (Calzavara, 1987). Sua inflorescência conhecida por cacho é formada por um conjunto de ramos, contendo um número variável de flores masculinas e femininas. Após a abertura e fecundação, as flores necessitam de aproximadamente cinco a seis meses para que os frutos atinjam a fase de maturação. Em média, uma inflorescência possui aproximadamente três vezes mais flores masculinas (Jardim, 1991).

A fecundação é geralmente cruzada, tendo em vista que a alogamia é mais comum em virtude do alto grau de auto-incompatibilidade, bem como do assincronismo de maturação dos órgãos de reprodução (Calzavara, 1972; Bovi et al., 1986; Jardim, 1991; Oliveira, 1995). Ohashi (1990) também chegou à conclusão que o açaizeiro é preferencialmente de fecundação cruzada. Todavia, a autogamia é possível, gerando redução de heterozigozidade na população. 
O fruto é uma drupa séssil, globoso, de superfície lisa (glabra), de cor violeta a quase negro, quando maduro e com 2,6 a 3,0 g. Possui pericarpo com cerca de $1 \mathrm{~mm}$ de espessura, parcialmente fibroso e destacável da semente (Calzavara, 1987; Oliveira, 1995).

A dispersão dos frutos e sementes é feita a curtas distâncias por pequenos animais roedores; a longas distâncias por tucanos, jacús, araçarís, periquitos, papagaios e sabiás. Os rios que invadem as matas das várzeas também auxiliam na dispersão (Jardim, 1995).

Jardim \& Anderson (1987) relatam que o açaizeiro floresce o ano inteiro com pico de floração na estação chuvosa (fevereiro a abril) e pico de frutificação na estação seca (setembro a outubro). Em estudos realizados no Instituto Agronômico de Campinas - IAC, o açaizeiro apresentou dois picos de florescimento (de abril a julho e de outubro a novembro), onde as condições de temperatura e umidade são adversas às encontradas em seu habitat natural. (Bovi, 1984; Bovi et al., 1986; Bovi et al., 1987)

O palmito de E. oleracea apresenta sabor, textura e coloração semelhantes ao $E$. edulis e suporta exploração em escala industrial. O que os difere é o poder de brotação (perfilhamento) do E. oleracea, com uma planta formando touceiras, muitas vezes com mais de 20 estipes e estas ocorrendo em grandes concentrações naturais.

\subsubsection{Potencial socioeconômico e manejo do açaizeiro}

Como conseqüência da exploração intensiva do palmiteiro (Euterpe edulis) nas Regiões Sul e Sudeste do Brasil, levando à quase extinção da palmeira. No final da década de 60 muitas indústrias de palmito migraram para a Região Norte, principalmente para o Estado do Pará, deslumbrados com a possibilidade de explorarem palmito de $E$. oleracea, espécie similar ao palmiteiro, com características peculiares que permitem a extração do palmito sem causar a morte da planta, devido ao fato dessa formar touceiras com muitos estipes e ser abundante em todo o estuário amazônico. Até então, a importância do açaizeiro em termos comerciais estava limitada a seus frutos.

Para as pessoas que habitam na região do estuário amazônico, o açaizeiro é aproveitado integralmente. A raiz é utilizada como vermífugo, o estipe adulto é utilizado 
como esteio em construções rústicas, ripas para cerca, lenha para olaria. As folhas são utilizadas na cobertura de casa, artesanato e, quando verdes, usadas como ração animal. O caroço (amêndoa e endocarpo) é decomposto e largamente empregado como matéria orgânica. Os cachos servem como vassouras, adubo e cobertura morta (Jardim \& Anderson, 1987). Contudo, os principais produtos economicamente rentáveis, utilizados nas indústrias alimentícias, são os frutos e o palmito.

Após a maceração da polpa do fruto, obtém-se a bebida chamada de "açál". Segundo as normas do Ministério da Agricultura (Brasil, 1998), a bebida pode ser classificada como açaí fino, médio ou grosso, variando com a proporção de água adicionada ao processo e, principalmente, a textura (Rogez, 2000). É consumido como complemento ou até mesmo como alimentação principal de diferentes classes populares. A polpa dos frutos também pode ser utilizadas no preparo de sorvetes, cremes, licores, geleias, tortas, e mingau, adubo, curtimento de couro, álcool carburante ou como antidiarréico (Jardim \& Anderson, 1987).

Segundo Mourão (1999), o consumo médio de açaí na cidade de Belém em 1989 alcançou 200.000 litros/dia e em 1996 duplicou, o que representa 2 vezes a mais que o consumo em leite na cidade. No estuário amazônico (Estados do Pará e Amapá), estimase que o consumo médio por pessoa seja de 27,7 litros/ano, o que faz do açaí o segundo alimento mais consumido nestes Estados, depois da farinha de mandioca (Alves, 1992).

Nos últimos anos, o consumo nacional da bebida açaí vem aumentando significativamente. Principalmente na Região Sudeste, essa bebida é alvo do público jovem, que é atraído pelas suas propriedades calóricas e energéticas e alcança alto valor comercial. O açaí é comercializado sob forma congelada, freqüentemente muito diluído e consumido junto a outras frutas (acerola, morango, kiwi, castanha, guaraná, entre outras).

O Rio de Janeiro, que importou apenas 5 t/ano de açaí em 1992, aumentou sua importação para 180 t/mês em 1996. Neste mesmo ano, os Estados de Goiás, São Paulo, Minas Gerais e Rio Grande do Sul importaram 300 t/mês de açaí. Já em 1997, esse valor dobrou durante o verão (Mourão, 1999), significando aumento de divisas para os Estados produtores da bebida. 
A produção nacional de palmito foi bastante considerável no final da década de 80, chegando a 202.439 t em 1989, sendo que o Estado do Pará, foi o responsável por $92 \%$ do total de palmito comercializado. No ano seguinte, a produção teve uma queda significativa passando a $27.031 \mathrm{t}$ que, segundo Mourão (1999), provavelmente reflete a aplicação da nova legislação definida em 1988, a qual exigia maior qualidade do produto por parte do mercado internacional e principalmente à quase dizimação de açaizais adultos. Em 1995, a produção nacional diminuiu para $20.653 \mathrm{t}$, das quais $17.001 \mathrm{t}$ provinham do Pará (IBGE, 1995).

Para os habitantes do estuário, a extração de palmito é uma alternativa econômica, visto que o consumo do palmito não faz parte de seu hábito alimentar (Costa, 2000). Na verdade este produto destina-se quase que exclusivamente, ao mercado de exportação tanto nacional quanto internacional (Mourão, 1999).

O manejo dos açaizeiros pode ser uma alternativa viável para o uso sustentável do ecossistema onde esta palmeira ocorre abundantemente. Isso é possível em função da viabilidade de exploração contínua dos frutos e palmito, por meio do gerenciamento adequado dos perfilhos.

Jardim \& Anderson (1987) afirmam que, para um manejo integrado, é conveniente que seja realizado um raleamento seletivo das espécies florestais de menor valor econômico devido à concorrência com as touceiras, por luz e nutrientes e um desbaste seletivo de perfilhos, facilitando assim a coleta dos frutos e viabilizando a regeneração natural. Com estas práticas, foi possível aumentar a produtividade de frutos por estipe e melhorar o acesso aos açaizais, facilitando também a obtenção de outros produtos da floresta.

Estudos realizados por Jardim \& Rombold (1994), em áreas exploradas de forma tradicional, realizando apenas desbaste seletivo nas touceiras, verificaram um aumento de $30 \%$ na produção de frutos.

$\mathrm{Na}$ Comunidade de Marajoí Município de Gurupá-PA, os moradores manejam as populações de açaizeiros nativos, utilizando técnicas que envolvem o desbaste de estipes altos, finos e com baixa produtividade de frutos; raleamento por corte ou anelamento de espécies arbóreas sem valor econômico local ou utilizadas como lenha. Estes 
tratamentos, permitem obter frutos e palmito de excelente qualidade para comercialização, além de garantir a rotatividade de produção promovendo a conservação da espécie (Mesquita \& Jardim 1996).

Segundo Rogez (2000), dependendo de sua localização os municípios optam por produzirem frutos ou palmito, raramente os dois produtos. Os municípios próximos aos centros de comercialização preferencialmente produzem o fruto, por ser este mais lucrativo, enquanto que em municípios mais afastados produzem palmito, em virtude de um maior período de conservação e por ser necessária uma área maior para exploração sustentável.

\subsection{Aspectos ecológicos}

\subsubsection{Estrutura de população}

A estrutura populacional de uma espécie, ou seja, o conjunto de suas características demográficas e genéticas, é resultado de mecanismos ecológicos e evolutivos (Martins, 1987). Estudos demográficos em populações vegetais naturais são importantes para o entendimento do comportamento das plantas em seu ambiente específico e possíveis predições para o futuro (Agren, 1990; Silva, 1991).

Estes estudos propiciam informações que podem possibilitar elaborar medidas e práticas sustentáveis para o manejo da espécie, permitindo a manutenção da espécie em seu habitat natural. Além do que, podem identificar fatores ambientais que contribuem para variações com relação ao número de indivíduos, crescimento, desenvolvimento e capacidade reprodutiva da espécie (Sarukán et al., 1984).

Para a descrição da estrutura de uma população, é necessário que sejam estabelecidas classes que correspondam às diferentes etapas de desenvolvimento da planta. Essas classes podem ser caracterizadas com base no tamanho, idade cronológica ou por estádios ontogenéticos (Fisch, 1998).

Nas análises demográficas de palmeiras, Tomlinson (1990) considera que as classes de tamanho são mais significativas do que as classes de idade, por ser aquele um 
melhor indicador do status ecológico que a idade, devido à imprecisão no método morfológico e anatômico para esta medida.

Os indicadores dos estádios geralmente utilizados são as alterações morfológicas, por indicarem, de forma discreta, as mudanças anatômicas, fisiológicas e bioquímicas, resultantes de processos contínuos do desenvolvimento da planta (Gatsuk et al., 1980). As alterações morfológicas caracterizam-se pelo surgimento e extinção de estruturas na planta, representando assim estádios de desenvolvimento, independentemente da sua idade cronológica (Silva, 1991). Medidas de tamanho, como diâmetro, altura, número de folhas e área foliar também caracterizam os estádios ontogenéticos (Carvalho, 1994).

Embora a duração média de cada estádio ontogenético seja fixada geneticamente, indivíduos da mesma idade podem estar, na mesma época, em diferentes estádios de desenvolvimento (Gatsuk et al., 1980). Segundo Danciguer (1996), essas diferenças dependem do resultado da variabilidade genética intrapopulacional, da plasticidade fenotípica dos indivíduos e das condições ambientais específicas do sítio de desenvolvimento de cada planta.

Estudos demográficos com palmeiras estão sendo amplamente realizados devido à fácil identificação morfológica das espécies e principalmente pela ampla abundância de indivíduos em todos os estádios de desenvolvimento da planta (Ribeiro, 1991).

A classificação das populações de palmiteiro em estádios ontogenéticos vem sendo estudada por vários pesquisadores. Silva (1991) estudou uma população de palmiteiro presente em uma mata mesófila na Região de Campinas-SP, a partir da classificação dos indivíduos em quatro estádios (plântula, jovens, imaturos e adultos), baseado em características morfológicas e fisiológicas. Carvalho (1994), que estudou a mesma população de Silva (1991), considerou apenas os estádios iniciais de desenvolvimento do palmiteiro, estes foram classificados em plântulas, infantes e jovens, segundo alterações morfológicas e características foliares. Numa floresta ombrófila densa (Blumenau-SC), Reis et al. (1996) classificaram uma população de E. edulis em seis estádios de tamanho (plântula, jovens I, jovens II, imaturo I, imaturo II e adultos), adaptando a classificação proposta por Silva (1991), levando-se em consideração a altura, o número e o tipo de folhas. Tonetti (1997) estudou outra população de palmiteiro no 
Paraná, dividindo-a em cinco estádios de tamanho (plântulas, planta jovem I e II, imaturos e adultos). Fisch (1998) usou caracteres foliares para classificar sua população de estudo em cinco estádios ontogenéticos (plântula, infante, jovem, adulto vegetativo e adulto reprodutivo) na Reserva Ecológica do Trabiju (Pindamonhangaba-SP).

Pimenta (1991) estudou sob o enfoque demográfico a palmeira Manicaria martiana Burret (bussu), dividindo a população em dois estados: acaulescente e com caule. O primeiro estado, que representa $95-96 \%$ da população, foi dividido em quatro estádios (plântula, juvenil I e II, jovem acaule), enquanto que o segundo foi dividido em dois (adulto e adulto pré-reprodutivo), ambos em função da morfologia foliar da palmeira.

A distribuição de tamanho de espécies arbóreas é comumente utilizada para representar a estrutura da floresta (Harper, 1977). A estrutura de tamanho de espécies não-pioneiras ou tolerantes à sombra, apresenta-se de forma desigual, com maior número de indivíduos nas menores classes de tamanho (Hubbell \& Foster, 1987), isso se deve à capacidade de regeneração e sobrevivência das espécies no estrato inferior da floresta. Os mesmos autores consideram este tipo de estrutura de tamanho ("J invertido"), como sendo um indicativo de estabilidade populacional.

A desigualdade na distribuição dos tamanhos entre os indivíduos é chamada de hierarquia (Weiner \& Solbrig, 1984), com poucos indivíduos contribuindo para a maior parte da biomassa populacional. Os principais fatores que podem promover esta desigualdade de tamanho entre os indivíduos de uma população, estão relacionados à herança genética e à competição intraespecífica (Hutchings, 1986).

A curva de distribuição de frequência em forma de $J$ invertido é citado como característica de população da espécie Euterpe edulis (Silva, 1991; Alves, 1994; Reis, 1995; Tonetti, 1997; Fisch, 1998) e de outras espécies arbóreas (Martini, 1996; Caldato et al., 1999; Alves, 2000; Marques et al., 2000).

O padrão espacial de uma espécie caracteriza a forma como os indivíduos estão distribuídos na área, sendo uma das características da estrutura populacional. Vários autores discutem diferentes causas que podem determinar o padrão espacial de distribuição dos indivíduos das espécies arbóreas na floresta. Segundo Greig-Smith 
(1983), fatores ambientais e/ou bióticos podem influenciar diretamente o padrão espacial dos indivíduos de uma espécie. O padrão depende também da densidade das sementes dispersadas, da capacidade de sobrevivência das plântulas, da influência de fatores de mortalidade e das interações intra e interespecíficas (Janzen, 1970; Hubbell, 1980; Hutchings, 1986).

Os indivíduos de uma população podem estar distribuídos de acordo com três padrões: aleatório, uniforme e agregado. O padrão aleatório, é aquele no qual os indivíduos estão dispersos ao acaso, geralmente em um ambiente uniforme e não há tendência à agregação. No uniforme, os indivíduos estão mais ou menos eqüidistantes entre si, isso pode ocorrer devido a competição. E finalmente, o agregado que é o padrão mais comum, onde os indivíduos distribuem-se em grupos de forma irregular (Odum, 1988; Pires-O'Brien \& O'Brien, 1995). O padrão espacial pode variar de acordo com a escala de tamanho e durante a ontogenia dos indivíduos de uma população, sendo que, em escala local, o padrão é agregado, raramente aleatório ou regular (Hutchings, 1986).

Segundo Bawa (1992), a grande maioria das espécies arbóreas tropicais são alógamas, provavelmente devido a altas taxas de auto-incompatibilidade ou por serem dióicas. A alogamia encontrada nessas espécies está intimamente ligada à polinização por animais (Bawa, 1974). Assim, o padrão de distribuição espacial dos indivíduos de uma espécie pode ser conseqüência do tipo de polinização e de dispersão das sementes, visando atender a especificidade do agente polinizador e dispersor (Kageyama, 1990).

Os resultados obtidos com a análise do padrão espacial das espécies arbóreas podem ser usados para definir sistemas de amostragem mais adequados em inventários florestais, além de um melhor planejamento de exploração, levando em consideração a regeneração natural da espécie a ser manejada.

Tendo em vista o avanço científico no campo da ecologia e genética de populações de espécies tropicais, o manejo florestal não pode ser mais concebido como uma prática comum para todas as espécies florestais de valor econômico, mas sim, por ações direcionadas por espécies ou grupos de espécies com comportamento ecológico similar. Dessa forma fica evidente que o manejo florestal dito sustentado deve ser respaldado por informações básicas sobre a ecologia das espécies, levando em 
consideração o seu grupo sucessional, a forma com que os indivíduos estão estruturados e distribuídos nas populações. Quanto aos aspectos genéticos, as informações a serem consideradas serão abordadas a seguir.

\subsection{Aspectos genéticos}

\subsubsection{Variabilidade genética em populações naturais}

A genética de populações tornou-se uma ferramenta importante devido sua finalidade de descrever a variação genética em populações e estudar os mecanismos de manutenção dessa variabilidade (Nei, 1987).

Moran et al. (1987) destacam a necessidade da definição de padrões de variação genética em plantas, para a simplificação das estratégias de conservação genética. Os autores consideram ainda que, para se chegar a modelagem pretendida da estrutura genética das espécies arbóreas da floresta tropical, devem ser definidas espécies-modelo com diversidade genética bem conhecida.

Perecin (2000) aborda que a grande variedade, em termos de magnitude e distribuição da variação genética entre e dentro das populações das espécies tropicais, requer estudos específicos para as espécies a serem manejadas, conservadas e domesticadas.

Para quantificar a variabilidade genética, Frankel et al. (1996) consideram dois diferentes aspectos de diversidade: a riqueza alélica, medida através do número total de alelos na população ou amostra $(A)$, e a eqüitabilidade na frequência dos diferentes alelos presentes na população, medida pelo coeficiente de diversidade gênica (He). Outros índices também utilizados são a heterozigosidade observada $(\mathrm{Ho})$, percentagem de locos polimórficos e o índice de fixação de Wright $(f)$.

Segundo Weir (1990), as análises de dados genéticos devem ser baseados em modelos biológicos. O modelo clássico que considera a população infinita, sob cruzamento ao acaso para um loco (panmítica) e sobre a qual não atuam forças perturbadoras de mutação, migração ou seleção, é o Teorema de Hardy-Weinberg (HW). 
Outro modelo considerado é o Equilíbrio de Endogamia Neutro de Wright (EENW) conhecido como o modelo de cruzamento misto. Esse modelo é denominado de misto porque considera, no sistema de reprodução, acasalamentos aleatório e autofecundação (Brown \& Weir, 1983).

A distribuição da variação genética em espécies de fecundação cruzada, monóica e/ou dióica, de ciclo longo e clímax é caracterizada por apresentar uma baixa variação entre populações e uma alta variação dentro da população (Loveless \& Hamrick, 1984). Por outro lado, Bawa (1992) menciona que para as espécies arbóreas tropicais a diversidade genética intrapopulacional é consideravelmente alta e que a diferenciação genética entre populações varia dependendo da espécie.

Estudos relacionados à variação genética em populações naturais de espécies arbóreas tropicais requerem a utilização de técnicas de quantificação da diversidade genética, bem como uma adequada amostragem das populações (Kageyama et al., 2001). Inicialmente utilizavam-se técnicas de genética quantitativa por meio de testes de progênies e procedências (Ohashi, 1990) e, posteriormente, marcadores genéticos isoenzimáticos e moleculares, resultando em um número razoável de estudos com espécies arbóreas tropicais (Gandara, 1996; Grattapaglia et al., 1998).

Em uma extensa revisão, Hamrick \& Godt (1990) analisaram 449 espécies vegetais, a partir de dados de isoenzimas. Observaram que, em média, 50,5\% dos locos considerados eram polimórficos, apresentando aproximadamente dois alelos por loco e a diversidade genética em torno de 0,15 .

Negrão (1999) estudou três populações da palmeira Syagrus ramanzoffiana (Jerivá) por meio de marcadores isoenzimáticos, e obteve valores médios populacionais de diversidade gênica $(\mathrm{He})$ de 0,241 , heterozigosidade observada $(\mathrm{Ho})$ de 0,243 e número de alelos por locos $(A)$ igual a 1,96 .

A partir de sete locos alozímicos Reis (1996), analisou a diversidade genética em populações de Euterpe edulis. O autor estimou o número médio de alelos por loco $(3,2)$, a heterozigosidade observada $(0,432)$ e a diversidade gênica $(0,435)$ em progênies e adultos de 7 populações desta espécie. Estes resultados indicaram um alto grau de diversidade para a espécie, considerando os marcadores empregados. 
Também em duas populações de Euterpe edulis, foram detectados níveis elevados de diversidade genética para 18 locos de microssatélites Gaiotto (2001). Em média, foram obtidos 10,8 alelos por loco, a heterozigosidade observada e a diversidade gênica de 0,690 e 0,749 , respectivamente. Esses resultados confirmam a alta diversidade genética presente em populações desta espécie e o elevado conteúdo de informação genética esperada para o marcador de DNA do tipo microssatélite

\subsubsection{Taxa de cruzamento e fluxo gênico}

Em estudos de população o conhecimento da distribuição geográfica, modo de reprodução, sistema de cruzamento e mecanismos de dispersão de sementes, são importantes no entendimento da distribuição da sua variabilidade genética (Hamrick 1983).

O sistema de cruzamento determina o modo de transmissão dos genes de uma geração à outra (Brown, 1990). Dada a sua grande importância para a espécie, alguns parâmetros são afetados diretamente pelo sistema de cruzamento, tais como: a relação genética existente entre progênies, diversidade genética intrapopulacional e a distribuição da diversidade entre e dentro das populações (Hamrick \& Murawski, 1990).

Devido à diversidade das formas do sistema reprodutivo nas espécies, variando desde reprodução assexuada até os sistemas com endogamia completa e alogamia, os padrões de distribuição de variabilidade genética entre e dentro das populações das espécies são diferentes. Em espécies autógamas, há uma baixa variação genética dentro das populações e alta entre populações, enquanto que, em espécies alógamas, a maior variabilidade está presente dentro das populações (Hamrick, 1983).

O estudo do sistema reprodutivo de várias espécies tem sido realizado através da avaliação da biologia floral (Jardim, 1991), da ecologia de polinização e também através da estimativa da taxa de cruzamento, utilizando-se, principalmente, marcadores isoenzimáticos (Gandara, 1996). Segundo Bawa (1992), estudos de sistema reprodutivo com base na morfologia floral e polinizações controladas, não caracterizam o nível de cruzamento, apenas relatam a ocorrência de polinização cruzada. A taxa de cruzamento 
pode ser quantificada através de marcadores genéticos, utilizando-se progênies para indicar se a população está realizando autofecundação ou fecundação cruzada.

As estimativas da taxa de cruzamento têm sido obtidas a partir de duas metodologias. A primeira utilizando-se o método dos momentos, através da relação entre o coeficiente de endogamia $(f)$ e a taxa de cruzamento aparente $\left(t_{a}\right)$ (Weir, 1990; Vencovsky, 1992) e, a segunda, através de estimativas de máxima verossimilhança (Ritland \& Jain, 1981; Ritland \& El-Kassaby, 1985). Segundo Reis (1996), o uso de modelos multilocos permite a obtenção de estimativas mais adequadas da taxa de cruzamento porque eles consideram as combinações genotípicas envolvendo todos os locos. Atualmente, os estudos de determinação do sistema reprodutivo estão sendo realizados por meio de marcadores isoenzimáticos e moleculares.

Vários trabalhos com populações de espécies arbóreas tropicais, têm apresentado elevadas estimativas da taxa de cruzamento principalmente através de multilocos (O’Malley et al., 1988; Eguiarte et al., 1992; Hall et al., 1994; Gandara, 1996; Reis, 1996; Souza, 1997; Negrão, 1999; Gaiotto, 2001).

Hamrick (1983) verificou que em populações naturais existe alta associação entre o sistema reprodutivo e o fluxo de genes com a estrutura genética das espécies. O mesmo autor ressalta que a dispersão de pólen e sementes é um importante processo que afeta o fluxo gênico entre e dentro de populações de espécies arbóreas, alterando a distribuição espacial e estrutura genética das espécies. O fluxo de genes influencia no tamanho efetivo populacional, como um delimitador das populações, além de homogeneizar a composição genética das mesmas (Futuyma, 1992).

Segundo Reis (1996), o fluxo gênico caracteriza a dinâmica de movimentação de alelos em populações naturais. Futuyama (1992) descreve quatro modelos para explicar como o fluxo gênico atua em populações estruturadas: i) continente-ilha, no qual o movimento de alelos é unidirecional da população grande para outra menor e/ou isolada; ii) ilhas, ocorre migração ao acaso entre um grupo de pequenas populações bem definidas; iii) alpondras (stepping-stone), há troca de migrantes apenas entre populações vizinhas; iv) o modelo do isolamento por distância, o fluxo gênico ocorre entre grupos vizinhos, em uma população de distribuição contínua. 
As estimativas de fluxo gênico podem ser obtidas por métodos diretos e indiretos. Os métodos diretos estimam as distâncias de dispersão e o sucesso no estabelecimento dos dispersores por inferirem na magnitude do fluxo gênico no espaço e no tempo (Perecin, 2000). O teste de paternidade é um método direto de avaliar fluxo gênico em populações naturais. Este pode ser realizado por meio da técnica de microssatélite (Gaiotto, 2001), e o modelo de estimação foi descrito por Weir (1996).

Os microssatélites são seqüências repetidas em tandem de 1 a 6 pares de base, as quais são altamente polimórficas para o número de repetições (Ashley \& Dow, 1994). A amplificação da região do microssatélite, por "reação de polimerase em cadeia" (PCR), resulta em marcadores codominantes que apresentam alta variabilidade para determinar a exclusão de paternidade. Cada loco microssatélite tem muitos alelos raros (alelos com baixa freqüência na população) e, na maior parte dos casos, todos os adultos na área podem ser excluídos da paternidade usando-se apenas alguns locos (Silva, 2000).

O objetivo dos testes de paternidade é encontrar tantos alelos compartilhados quanto possível entre dois indivíduos, de forma que se possa estimar, estatisticamente, a existência da relação de descendência do tipo "progenitor-progênie" entre os indivíduos avaliados (Gaiotto, 2001).

\subsubsection{Marcador molecular microssatélite}

Microssatélites ou seqüências simples repetidas (SSR - Simple Sequence Repeats) são marcadores relativamente novos baseados em repetições curtas (de 1 a 6 pares) de bases (Litt \& Luty, 1989), repetidas lado a lado. Eles representam regiões instáveis do genoma que estão sob alterações mutacionais a taxas maiores que as observadas nas seqüências de taxa única.

A instabilidade dos microssatélites resulta em marcadores altamente polimórficos, multialélicos, que são extremamente úteis em estudos de genética de populações arbóreas tropicais. Os alelos diferem por mostrarem números diferentes de repetições em tandem, oriundos de crossing over desigual durante a meiose ou ao deslize de DNA polimerase (strand-sllippage) durante a duplicação da molécula. 
Os microssatélites são suficientemente estáveis para serem utilizados como marcadores em análises genéticas. Diferentes alelos podem ser detectados em um loco por PCR, utilizando seqüências flanqueadoras conservadas para sítios de anelamento de primers. Eles são bons marcadores de DNA, pois são informativos em plantas e podem ser analisados por ensaio rápido e simples de PCR, além de abundantes e uniformemente distribuídos no genoma (Jarne \& Lagodada, 1996).

Os microssatélites podem ser diferenciados pela composição específica da seqüência fundamental (unidade repetitiva), sendo: i) repetições puras, os locos de microssatélites são formados por uma única unidade repetitiva; ii) repetições compostas, aquelas que apresentam mais de uma unidade repetitiva compondo o microssatétile; iii) repetições interrompidas, na qual a unidade repetitiva é intercalada por diferentes nucleotídeos.

Os microssatélites nas plantas (Condit \& Hubell, 1991) são cerca de cinco vezes menos abundantes que em humanos, onde ocorre um microssatélite (maior que 20pb) a cada $6 \mathrm{~Kb}$. Nas monocotiledôneas é esperado um microssatélite a cada $65 \mathrm{~Kb}$, enquanto nas dicotiledôneas um microssatélite a cada $21 \mathrm{~Kb}$.

Os marcadores microssatélites têm sido desenvolvidos de forma crescente para espécies arbóreas para as mais diversas aplicações, desde mapeamento genético em Pinus radiata (Smith \& Devery, 1994) e Eucalyptus sp. (Brondani et al., 1998), até estudos de genética de populações em Quercus macrocarpa (Dow et al., 1995; Dow \& Ashly, 1996), Pithecellobium elegans (Chase et al., 1996), Swietenia humilis (White \& Powell, 1997), Copaifera langsdorffii (Ciampi, 1999) e para Euterpe edulis (Gaiotto, 2001).

Apesar do alto custo tecnológico necessário para obtenção de pares de primers de microssatélite (Gaiotto, 2001), são muitas as vantagens do uso desse marcador. Tais vantagens, estão principalmente associadas à sua natureza multialélica, à herança codominante, à facilidade de detecção pela PCR, à abundância relativa e à cobertura extensa no genoma, além de permitir o intercâmbio entre laboratórios e de poderem ser transferidos entre espécies do mesmo gênero. 


\section{MATERIAL E MÉTODOS}

\section{1 Área de estudo}

A Estação Científica "Ferreira Penna" (ECFPn) é uma área protegida de 33.000 hectares, localizada no interior da Floresta Nacional de Caxiuanã (FLONA) (1 ${ }^{\circ} 42^{\prime} 30^{\prime}$ 'S x 51 31 '45"W), município de Melgaço, Estado do Pará, distante aproximadamente 400 km a Oeste da cidade de Belém (Figura 1). A ECFPn abrange diversos ecossistemas, destacando-se a floresta densa de terra firme, ocupando cerca de 80 a $90 \%$ do total da área, as florestas de várzea e igapó, sendo considerada uma das mais ricas zonas da Amazônia oriental, tanto em biodiversidade como em potencial econômico florestal. (Almeida et al., 1993).

O tipo climático da Região de Caxiuanã é Am (classificação de Kooppen), apresentando um clima tropical úmido com excesso de precipitação pluviométrica durante alguns meses, ocorrendo um ou dois meses (outubro e novembro) com pluviosidade inferior a $60 \mathrm{~mm}$. Na região, há um déficit hídrico no período compreendido entre o final de junho a meados de novembro, com um excedente entre janeiro a junho (SUDAM, 1984). Os meses de abril e maio registraram os maiores acúmulos deste excedente (Almeida et al., 1993).

A temperatura média anual é cerca de $26^{\circ} \mathrm{C}$, com os valores médios de temperatura mínima e máxima próximos de $22^{\circ} \mathrm{C}$ e $32^{\circ} \mathrm{C}$, respectivamente (SUDAM, 1984). A umidade relativa do ar fica em torno de $85 \%$. Os solos da área são classificados no grupo dos Latossolos Amarelos Distróficos de Textura Média (RADAMBRASIL, 1974). 
A FLONA de Caxiuanã apresenta grandes maciços naturais de Euterpe oleracea, espécie de valor sócio-econômico fundamental para as comunidades ribeirinhas da região e passíveis de extrativismo sustentável.
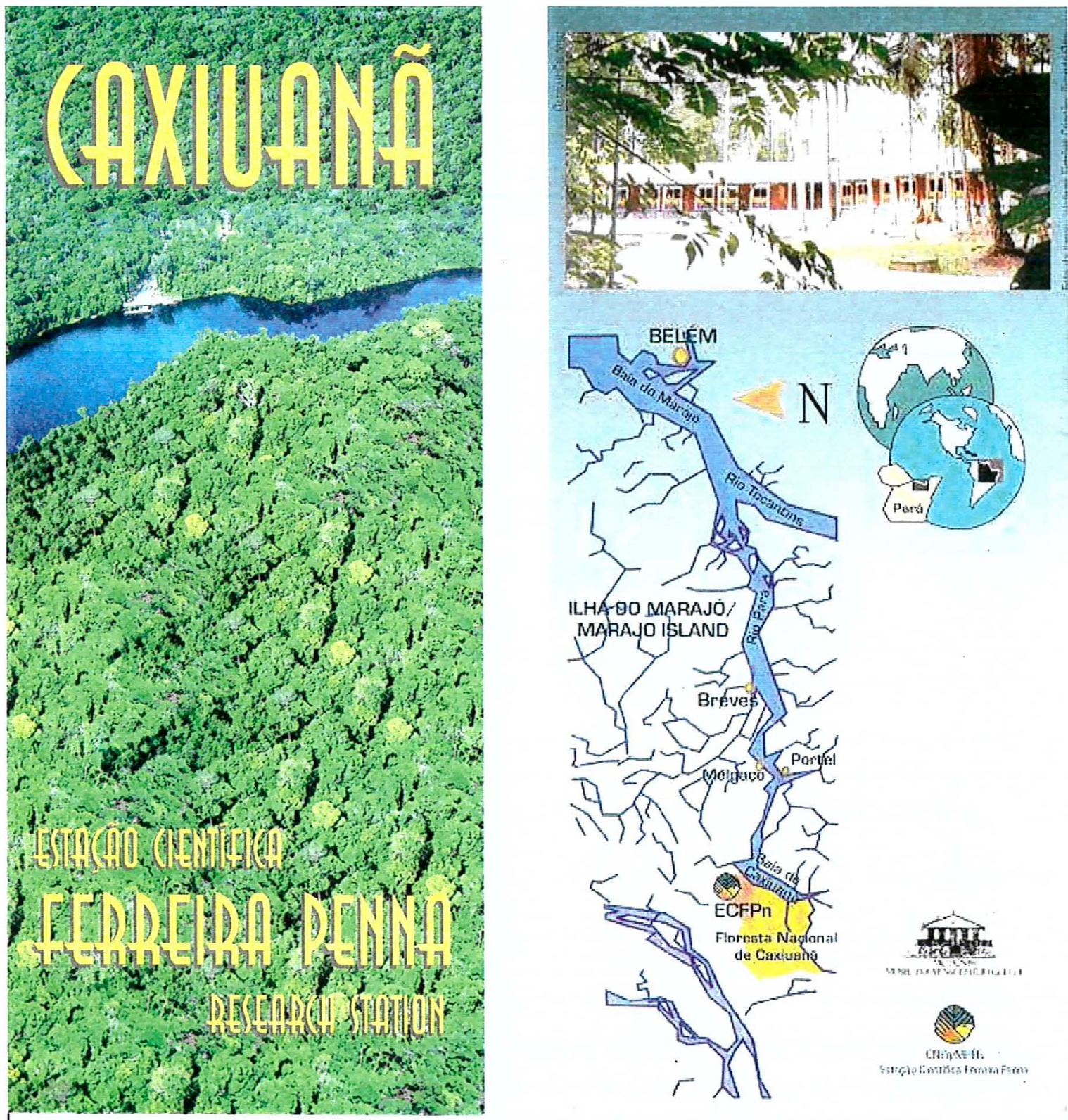

Figura 1 - Localização da área de estudo Estação Científica Ferreira Penna, situada no Município de Melgaço-PA. 


\subsection{Procedimento de campo}

\subsubsection{Levantamento da população}

Em um trecho de floresta de várzea, sem ação antrópica, na Floresta Nacional de Caxiuanã, Município de Melgaço-PA, onde a concentração de maciços naturais de açaizeiros (Euterpe oleracea Mart.) é predominante, uma área amostral contínua de 1,0 hectare foi demarcada e dividida em vinte e cinco parcelas de $400 \mathrm{~m}^{2}(20 \mathrm{~m} \times 20 \mathrm{~m})$. Dentro de cada uma das parcelas foram marcadas sub-parcelas de $4 \mathrm{~m}^{2}(2 \mathrm{~m} \times 2 \mathrm{~m})$ de forma sistematizada, sendo essas alocadas sempre no vértice direito de cada parcela (Figura 2).

Nas sub-parcelas, foi realizado o estudo das plântulas, sendo consideradas pertencentes a esse estádio todas as plantas com até três folhas abertas (Belin-Depoux \& Hering de Queiroz, 1971 apud Silva, 1991). Mensurou-se a altura total (AT) com ajuda de uma régua graduada e também contou-se o número de folhas presentes (NF) em todas as plântulas.

Nas parcelas de $400 \mathrm{~m}^{2}$ foram mensurados todos os estipes em estádio ontogenético superior ao de plântula, desses estipes foram mensurados, em uma única vez, o diâmetro à altura do peito (DAP) para as plantas com presença de estipe, a altura do estipe (AE), a altura total (AT) até a inserção da folha flecha, contado o número de folhas presentes (NF) e registrada a presença ou ausência de atividade reprodutiva (inflorescência e/ou infrutescência). Com o auxílio de uma fita diamétrica foi mensurado o diâmetro e através de uma vara graduada foram determinadas, a altura do estipe e a altura total das plantas.

$\mathrm{Na}$ demarcação da área de estudo e das parcelas, foram utilizadas bússolas, balizas e trenas. Todos os indivíduos de Euterpe oleracea, dentro de suas respectivas parcelas, foram mapeados pelo sistema de coordenadas arbitrárias ( $\mathrm{x}$ e y) e marcados com plaquetas metálicas devidamente numeradas. 


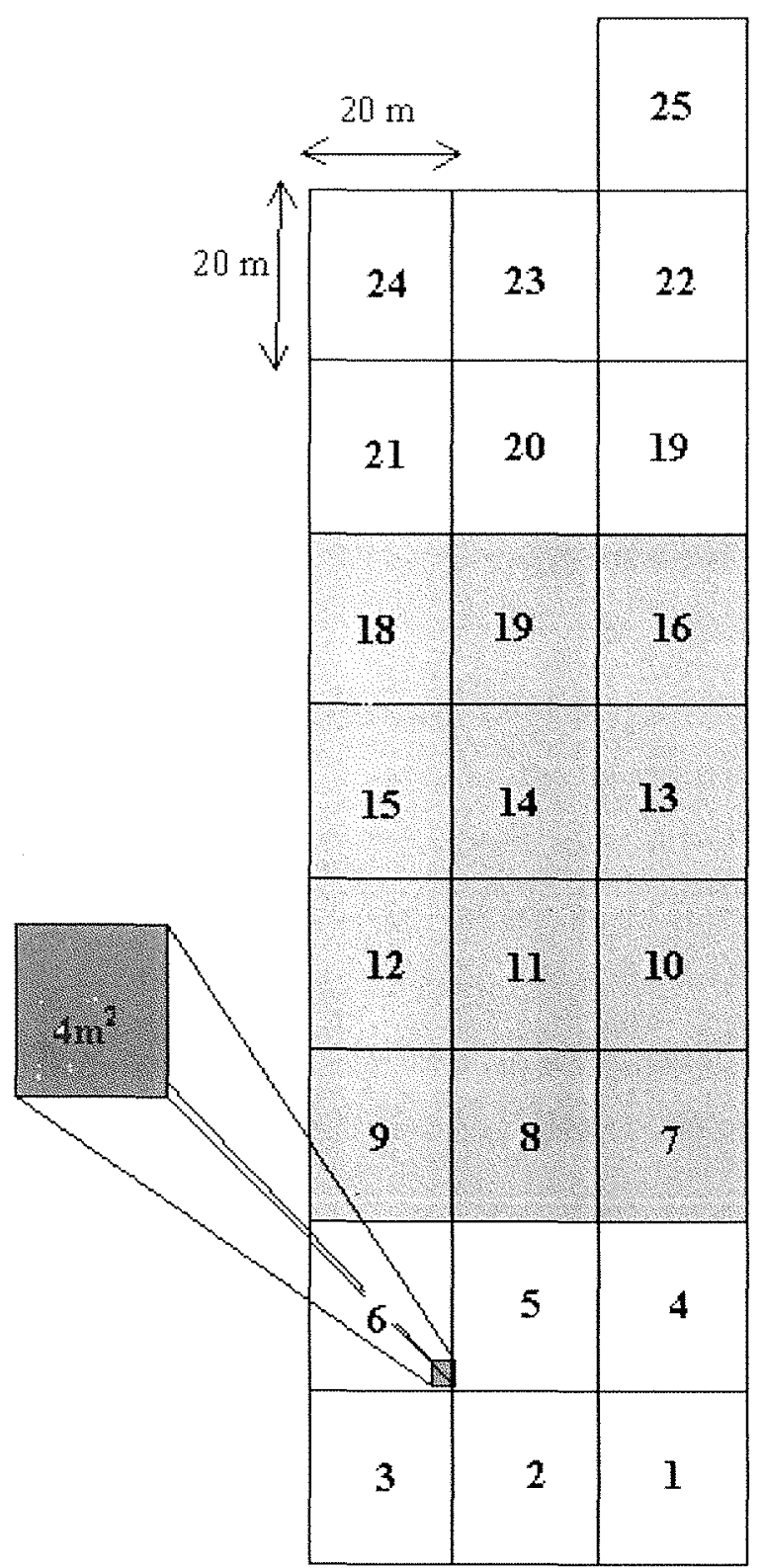

Figura 2 - Croqui da área de estudo, contendo as 25 parcelas de $400 \mathrm{~m}^{2}(20 \mathrm{~m} \times 20 \mathrm{~m})$, e a representação de uma das 25 sub-parcelas de $4 \mathrm{~m}^{2}(2 \mathrm{~m} \times 2 \mathrm{~m})$ para estudo das plântulas. A área pintada corresponde à da coleta de folhas de indivíduos adultos $\left(4800 \mathrm{~m}^{2}\right)$ na ECFPn, município de Melgaço-PA. 


\subsubsection{Coleta de material botânico}

Dentro da área amostral foram coletadas amostras foliares de todos os 98 indivíduos adultos, presentes em 12 parcelas consecutivas, sendo seis para cada lado partindo-se do centro da área (Figura 2, área pintada). Desta forma, genotipou-se todos os indivíduos adultos presentes em doze parcelas equivalente a $4800 \mathrm{~m}^{2}$.

As folhas foram coletadas com a ajuda de um podão, amostrando-se apenas as folhas em bom estado de conservação e em fase ativa de crescimento vegetativo. De cada folha foram escolhidos de 3 a 4 folíolos limpos e colocados em sacos de papel, devidamente numerados conforme a numeração da planta no campo. Esses foram conduzidos em potes fechados contendo sílica gel para absorver a umidade dos tecidos.

Dentre os 98 indivíduos que foram coletadas as folhas, nove deles, escolhidos de forma aleatória, tiveram seus frutos também coletados. Quinze sementes de cada indivíduo foram semeados no viveiro do Departamento de Ciências Florestais ESALQ/USP em Piracicaba-SP, com a finalidade de se obter progênies dessas nove matrizes. A partir dessas famílias maternas foram coletadas amostras foliares para análise genética.

\subsection{Protocolo de laboratório}

\subsubsection{Extração de DNA}

Para extração de DNA dos tecidos foliares, foi seguido o protocolo proposto por Ferreira \& Grattapaglia (1995), que consiste das seguintes etapas básicas:

Etapa 1 - Maceração mecânica das folhas liofilizadas dos indivíduos adultos do açaizeiro e das folhas frescas das progênies. Ambas foram maceradas em tubos eppendorf de $1,5 \mathrm{ml}$, na presença de nitrogênio líquido com a ajuda de um bastonete, para romper as paredes e membranas celulares do tecido. 
Etapa 2 - Ressuspenção do tecido macerado em $700 \mu 1$ do tampão de extração, contendo o detergente CTAB (brometo de cetiltrimetilamônio), antioxidante EDTA (ácido etileno diamono tetracético) e agente tamponante, visando a solubilização de membranas lipoprotéicas e desnaturação de proteínas, enquanto o DNA é protegido da ação de enzimas de degradação. Após a suspenção, as amostras foram submetidas à temperatura de $65^{\circ} \mathrm{C}$ em banho-maria, durante 60 minutos. A cada 10 minutos as amostras foram ligeiramente homogeneizadas para facilitar a solubilização da suspensão.

- Etapa 3 - Extração do DNA com $600 \mu$ l de solvente orgânico e clorofórmio-álcool isoamílico (CIA 24:1), que desnaturam as proteínas tornando-as insolúveis à fase aquosa, onde se encontram os ácidos nucléicos. As fases orgânicas e aquosa foram separadas através de centrifugação. Nesta extração, lipídios, proteínas e a maioria dos polissacarídios são mantidos na fase orgânica, disposta na porção inferior no eppendorf, enquanto que o DNA, RNA e alguns polissacarídios são mantidos na fase aquosa (superior), que é transferido para um novo tubo.

Etapa 4 - Precipitação do DNA, com o uso de $400 \mu \mathrm{l}$ de isopropanol $\left(-20^{\circ} \mathrm{C}\right)$. O DNA na presença de sal e álcool forma um precipitado (pellet), que se torna visível após ser centrifugado durante 10 minutos a uma rotação de $7000 \mathrm{rpm}$.. Gentilmente, derramou-se o sobrenadante e depois lavou-se o pellet por 2 vezes com etanol $70 \% \mathrm{e}$ 1 vez com álcool absoluto. Deixando o pellet secar por algumas horas ou de um dia para o outro.

$>$ Etapa 5 -Purificação o DNA com a ressuspensão do pellet, em $300 \mu$ de tampão Tris-EDTA contendo RNAse $(10 \mu \mathrm{g} / \mathrm{ml})$, para degradar o RNA restando apenas DNA genômico. Posteriormente, as amostras foram colocadas em estufas a $37^{\circ} \mathrm{C}$ por 45 minutos para a digestão do RNA.

Após as etapas de extração e purificação do DNA genômico, a material foi quantificado por meio da técnica de análise comparativa de cada amostra com o DNA fago $\lambda$ de peso conhecido, tendo sido coradas com brometo de etídio em gel de agarose a $1 \%$. 
Foram utilizados, em cada gel, DNA $\lambda$ padrão com concentração conhecida (50, 100 e $300 \mathrm{\eta g} / \mu \mathrm{l}$ ) dispostos lado a lado no gel possibilitando comparar com cada amostra de trabalho. Após a realização da corrida em cuba, utilizando-se a técnica de eletroforese. A estimativa das concentrações das amostras foi feita em imagem digital após a exposição do gel sob luz ultravioleta com base na intensidade luminosa de cada banda.

Como cada amostra de trabalho apresentou uma concentração diferenciada de DNA, variando de 50 a $300 \eta$ g de $\mathrm{DNA} / \mu \mathrm{l}$, todas as amostras foram diluídas, para a

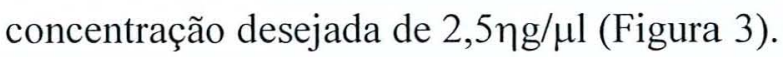

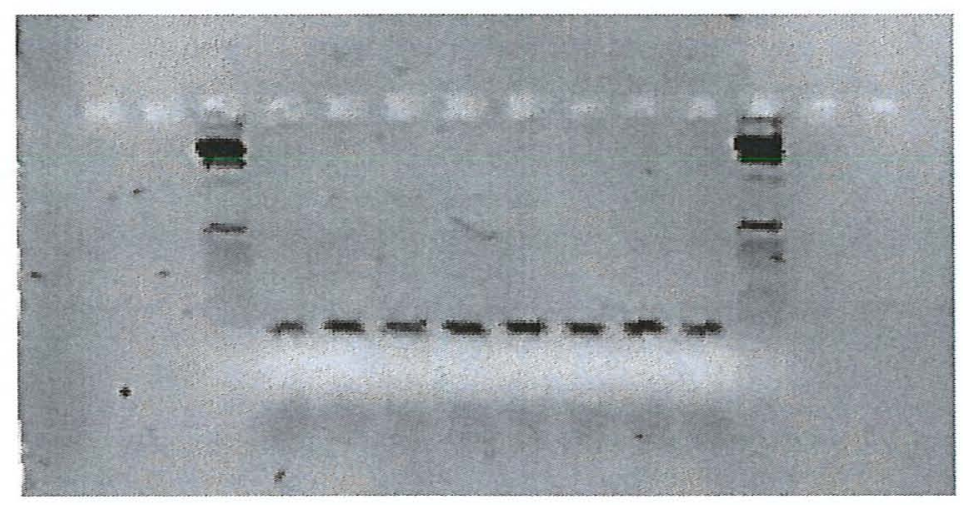

Figura 3 - Gel de agarose $1 \%$, com oito amostras de trabalho a $2,5 \eta \mathrm{g} / \mu \mathrm{l}$ e duas alíquotas laterais, de 10pb do ladder (Gibco).

\subsubsection{Obtenção de marcadores microssatélites}

A etapa subsequente é a reação de polimerase em cadeia (PCR - Polymerase Chain Reaction), que permite replicar in vitro milhões de cópias de um segmento específico de DNA na presença da enzima DNA polimerase. A reação de amplificação é conduzida por dois iniciadores (primers), oligonucleotídeos que hibridizam-se aos flancos opostos de cada uma das duas fitas de DNA desnaturada, em torno da região do DNA alvo. Ciclos consecutivos de desnaturação do DNA molde contento o alvo, mais o anelamento do primer e a extensão do DNA, sob temperaturas apropriadas, resultam em grandes quantidades de DNA de uma seqüência específica de interesse (Ferreira \& Grattapaglia, 1995). 
Foram utilizados cinco pares de primers para amplificação das regiões de microssatélite em Euterpe oleracea, sendo estes desenvolvidos e caracterizados por Gaiotto et al. (2001) no Laboratório de Genética de Plantas no CENARGEN-EMBRAPA em Brasília. Os autores transferiram 7 locos de microssatélite de Euterpe edulis para Euterpe oleracea, desses utilizamos 5 (Tabela 1) na estimação de parâmetros genéticos.

Tabelal - Locos microssatélites dinucleotídios utilizados, com suas respectivas temperaturas de anelamento $\left(T_{a}\right)$.

\begin{tabular}{ccc}
\hline Locos & Unidade Repetida & $\mathbf{T}_{\mathbf{a}}\left({ }^{\mathbf{0}} \mathbf{C}\right)$ \\
\hline EE3 & $(\mathrm{AG})_{11}(\mathrm{AG})_{16}$ & 56 \\
EE15 & $(\mathrm{AG})_{21}$ & 62 \\
EE25 & $(\mathrm{AG})_{20}$ & 58 \\
EE43 & $(\mathrm{AG})_{16}$ & 56 \\
EE54 & $(\mathrm{AG})_{25}$ & 56 \\
\hline
\end{tabular}

Cada reação de PCR foi composta por: $1,34 \mu$ de água MILIQ estéril; $1,30 \mu 1$ de

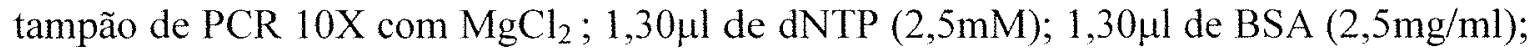
$0,26 \mu \mathrm{l}$ de $\mathrm{MgCl}_{2}(25 \mathrm{mM})$, suplementando o $\mathrm{MgCl}_{2}$ já contido no tampão $10 \mathrm{X} ; 4,3 \mu \mathrm{l}$ do par de primer $(0,9 \mu \mathrm{M}) ; 0,2 \mu \mathrm{l}$ de Taq DNA polimerase $(5 \mathrm{U} / \mu \mathrm{l})$ e $3 \mu \mathrm{l}$ de DNA de cada $\operatorname{amostra}(2,5 \eta g / \mu l)$.

As amplificações foram realizadas em termociclador, seguindo o protocolo de $96^{\circ} \mathrm{C}$ durante 2 minutos; 30 ciclos de $94^{\circ} \mathrm{C}$ durante 1 minuto, permitindo o anelamento específica para cada par de primers (Tabela 1), $72^{\circ} \mathrm{C}$ durante 1 minuto e terminando com $72^{\circ} \mathrm{C}$ durante 7 minutos.

As amostras foram aplicadas, em gel desnaturante de poliaclilamida 4\%, com espessura $0,4 \mathrm{~mm}$ e submetidas a eletroforese, sob potência fixa de $60 \mathrm{~W}$. O gel foi revelado utilizando-se solução $0,1 \%$ de nitrato de prata, de acordo com o protocolo descrito por Bassam et al.(1991). O tamanho dos alelos foi estimado por comparação com $10 \mathrm{pb}$ do ladder (Gibco) utilizado nas extremidades de cada gel. 


\subsection{Análise dos dados}

\subsubsection{Caracterização dos estádios ontogenéticos}

Os estádios de desenvolvimento de um indivíduo podem ser definidos por um conjunto de características quantitativas e qualitativas reconhecíveis no campo (Gatsuk et al., 1980). Logo, um dos procedimentos utilizados foi um levantamento prévio das características morfológicas, ou seja, características descontínuas que diferenciaram os diferentes estádios de crescimento da espécie, de modo a permitir acompanhar o seu desenvolvimento em estudos subsequentes, tentando verificar a contribuição de cada estádio para a manutenção da população.

Por ser uma espécie que apresenta perfilhamento com formação de touceiras, a população de Euterpe oleracea foi classificada em estádios ontogenéticos tanto por plantas (plântulas e estipes) quanto por touceiras (indivíduos). $\mathrm{Na}$ classificação por touceira, adotou-se, no presente estudo, dois critérios para escolher o estipe representativo da touceira.

Critério 1 - $\mathrm{O}$ estipe que apresentou a maior altura total foi escolhido como o representativo da touceira, desde que, não existisse outro estipe mais baixo com sinal de reprodução. Quando esta situação ocorreu, o estipe com sinal de reprodução foi escolhido como sendo o representativo;

Critério 2 - Caso dois estipes em uma mesma touceira apresentassem a mesma altura total, escolheu-se o de maior diâmetro para representar a touceira.

A classificação e descrição dos estádios ontogenéticos foi baseada nas observações macromorfológicas externas entre os individuos e nas informações disponíveis na literatura (Gatsuk et al., 1980; Silva, 1991; Carvalho, 1994; Reis, 1995; Dancinguer, 1996; Tonetti, 1997; Fisch, 1998; Flavio A. M. Santos, comunicação pessoal). Assim, foi possível escolher os caracteres mais convenientes para separar e caracterizar os estádios ontogenéticos. 
A delimitação dos estádios foi realizada com base na presença de caule e/ou palmito e nas análises de distribuição de frequência para altura do estipe, altura total e número de folhas. Para delimitar o estádio adulto considerou-se também a atividade reprodutiva (florescência e infrutescência) e/ou sinais de reprodução.

\subsubsection{Estrutura de tamanho da população}

Para descrever a estrutura de tamanho apresentado pela população de Euterpe oleracea presente na floresta de várzea em Caxiuanã, foi realizada a análise de distribuição de frequência para os dados de altura total das plantas (AT). Esta variável é considerada importante para estudos com palmeiras devido ao incremento em altura das palmeiras ser um indicativo do seu estádio de vida. Deve-se lembrar que, sendo a palmeira uma monocotiledônea, o crescimento em diâmetro ocorre somente durante a expansão celular (Tomlinson, 1980).

A variável AT foi determinada para todos os estipes e plântulas, enquanto que o DAP não pode ser medido para todos os estipes, por existir plantas sem o estipe formado, ou seja, que apresentavam apenas o palmito. A variável diâmetro no colo da planta é largamente utilizada em estudos demográficos com palmeira, entretanto, tal variável não foi possível ser empregada neste trabalho. A impossibilidade foi devido ao perfilhamento da espécie que, por formar densas touceiras, dificulta a visualização do colo da planta, impedindo as mensurações de diâmetro e, além disso, o microambiente nas touceiras (acúmulo de folhagens etc.) é propício para abrigar espécies peçonhentas.

Essa análise de distribuição de frequência para o estimador de tamanho AT foi realizado por plantas (plântulas e estipes) e por touceiras (indivíduos) em cada estádio ontogenético, para verificar se existia ou não a hierarquia de tamanho entre as plantas e entre as touceiras dos diferentes estádios ontogenéticos. 


\subsubsection{Distribuição espacial da população}

A distribuição espacial de uma espécie é uma das características da sua estrutura populacional. A análise dos dados foi baseada na presença e no número de indivíduos da espécie em cada parcela. O índice de Morisita (Id) proposto por Krebs (1989), foi calculado para verificar o padrão espacial dos estádios ontogenéticos estabelecidos para os estipes e touceiras. Este foi calculado a partir da seguinte fórmula:

$$
\mathrm{Id}=\mathrm{n} \frac{\sum \mathrm{x}^{2}-\mathrm{N}}{\mathrm{N}(\mathrm{N}-1)}
$$

Onde:

$\mathrm{n}=$ número de parcelas

$\mathrm{N}=$ número de plantas presentes nas parcelas estudadas

$\sum \mathrm{x}^{2}=$ somatória do quadrado do número de plantas por parcela

Se o índice de Morisita for significativamente menor do que 1, isso representa uma distribuição uniforme, se for maior do que 2, uma distribuição agregada e, se for igual a 1 , aleatória.

\subsubsection{Variabilidade genética intrapopulacional}

A variabilidade genética dentro da população foi caracterizada a partir das estimativas das freqüências alélicas e dos seguintes parâmetros para adultos e plântulas: número de alelos por loco $(A)$, diversidade gênica $(\mathrm{He})$, heterozigosidade observada $(\mathrm{Ho})$ e o índice de fixação de Wright (f).

Os parâmetros genéticos populacionais, foram estimados utilizando o programa GDA (Lewis \& Zaykin, 2002). 


\subsubsection{Taxa de cruzamento}

Para determinar o sistema reprodutivo da espécie na população estudada, foram utilizadas 9 famílias com 15 indivíduos (plântulas) em cada.

A caracterização da taxa de cruzamento na população foi obtido a partir da estimativa da taxa de cruzamento multilocos $(t m)$ e unilocos $(t s)$, obtidas segundo o método desenvolvido por Ritland \& Jain (1981), utilizando-se do programa MLTR, proposto por Ritland (1990).

Diferenças positivas entre $t m$ e $t s$ (tm-ts) permitem obter a taxa de cruzamento entre indivíduos aparentados e através da relação $(t m-1)$ é possível obter-se a taxa de autofecundação (s) na população. O programa também estima, a correlação entre as taxas de cruzamento dentro das progênies $(r t)$ e a correlação entre parentais de indivíduos resultantes de cruzamento dentro das progênies $(r p)$, que é a probabilidade de um par de indivíduos de uma mesma progênie serem irmãos germanos.

Em todas as análises realizadas os erros padrões das estimativas foram obtidos empregando-se 10.000 reamostragens ("bootstraps").

\subsubsection{Fluxo gênico}

O fluxo gênico foi determinado de forma direta pelo teste de paternidade, através do programa PATER (Silva et al., 2002).

O PATER (Program Paternity) é um software desenvolvido para ambiente Windows 95/98/NT, que permite fazer a identificação do parental masculino de um indivíduo a partir de um conjunto de possíveis "candidatos". Com base na análise do genótipo do parental feminino e prole, são calculados, segundo a herança monogênica, quais os possíveis genótipos do parental masculino. Esses padrões são comparados com os padrões dos possíveis parentais. À coincidência positiva, é atribuída a nota 1 e à não coincidência, a nota 0 . Após a análise de todos os locos obtêm-se uma média final. $\mathrm{O}$ parental masculino com maior média final, apresenta maior probabilidade $(\geq 80 \%)$ de ser o parental masculino do indivíduo investigado. 


\section{RESULTADOS E DISCUSSÃO}

\subsection{Caracterização dos estádios ontogenéticos}

Para esta população de Euterpe oleracea é possível distinguir quatro estádios ontogenéticos, sendo: Plântula, Jovem, Imaturo e Adulto (Figura 4). O estádio Imaturo foi subdividido em duas classes de tamanho, fazendo-se importante esclarecer que estas duas classes representam apenas divisões de tamanho (altura) e não estádios ontogenéticos das plantas. A caracterização dos estádios de Euterpe oleracea, tanto para as plantas como para as touceiras, foi realizada a partir de um mesmo conjunto de critérios morfológicos, da altura total e do número de folhas (Tabela 2).

O estádio de Plântula está representado por plantas acaules, com até $30 \mathrm{~cm}$ de altura total e com, no máximo, 3 folhas. A maioria das plântulas avaliadas ainda usufruíam de reservas endospermáticas da semente.

No estádio Jovem as plantas também são acaules, porém, apresentam o palmito exposto. Os indivíduos caracterizam-se por apresentarem altura total de até $2,5 \mathrm{~m}$, com 4 a 10 folhas Este estádio apresentou sobreposição de altura com o estádio de plântula; porém, a presença do palmito exposto e o número mínimo de quatro folhas, foram os critérios que diferenciaram.

O estádio Imaturo caracterizou-se por apresentar plantas com crescimento internodal formando um estipe exposto, mas ainda com ausência de atividade reprodutiva. Esse estádio foi dividido em duas diferentes classes de tamanho, devido a diferença em altura observada entre os estipes. 


\section{Classes de Tamanho:}

$\checkmark$ Imaturo I: as plantas apresentam altura total menor que $6 \mathrm{~m}$ e tem de 4 a 10 folhas.

$\checkmark$ Imaturo II: as plantas apresentam altura total maior ou igual a $6 \mathrm{~m}$ e tem de 5 a 13 folhas.

No estádio Adulto as plantas apresentam estipe e palmito expostos e assim como na classe de tamanho Imaturo 2, apresentam altura total mínima igual a $6 \mathrm{~m}$, presença de 5 a 12 folhas e sinal de reprodução (inflorescência e/ou infrutescência) durante o período de coleta dos dados.

Tabela 2 - Principais medidas dos estádios ontogenéticos para as plantas da população de Euterpe oleracea, incluindo o estádio de plântula, na ECFPn, Município de Melgaço-PA. AT = altura total $(\mathrm{m}), \mathrm{AE}=$ altura do estipe $(\mathrm{m}), \mathrm{NF}=$ número de folhas, DAP = diâmetro a altura do peito $(\mathrm{cm})$.

\begin{tabular}{lccccc}
\hline \multicolumn{1}{c}{ Estádios } & Plântula & Jovem & Imaturo I & Imaturo II & Adulto \\
\hline AT mín & 0,02 & 0,12 & 0,68 & 6,00 & 6,00 \\
AT máx & 0,30 & 2,50 & 5,90 & 25,00 & 26,00 \\
Média & 0,08 & 0,75 & 3,45 & 10,60 & 15,13 \\
\hline AE mín & - & - & 0,10 & 4,00 & 5,00 \\
AE máx & - & - & 5,20 & 24,00 & 25,00 \\
Média & - & - & 2,08 & 9,50 & 14,11 \\
\hline NF mín & 1,00 & 4,00 & 4,00 & 5,00 & 5,00 \\
NF máx & 3,00 & 10,00 & 10,00 & 13,00 & 12,00 \\
Média & 2,00 & 5,09 & 6,41 & 8,29 & 8,13 \\
\hline DAP mín & - & - & 0,50 & 4,70 & 6,00 \\
DAP máx & - & - & 9,90 & 15,00 & 22,80 \\
Média & - & - & 6,02 & 9,31 & 10,80 \\
\hline
\end{tabular}




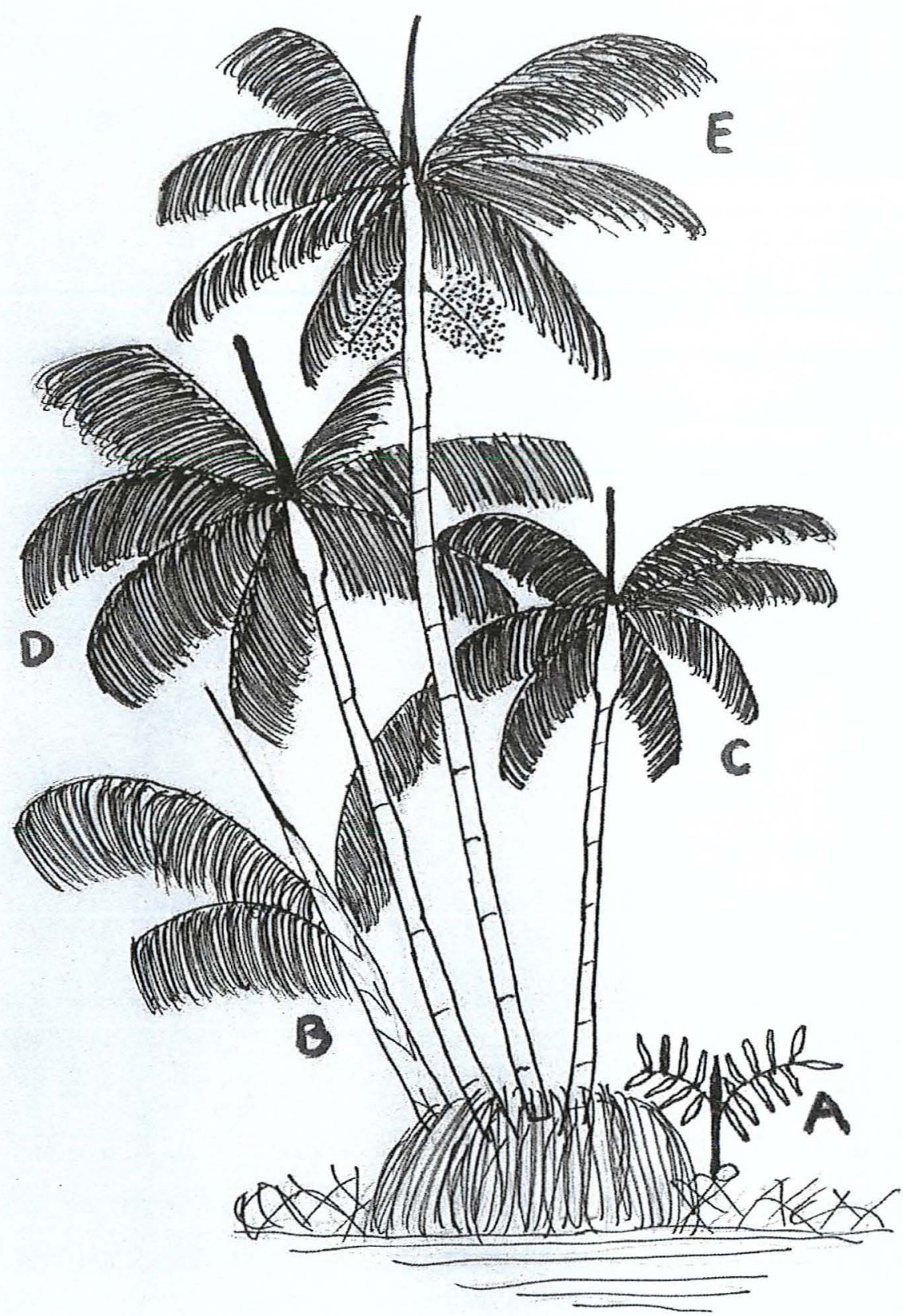

Figura 4 - Caracterização dos estádios ontogenéticos em uma touceira de Euterpe oleracea Mart. A - Plântula; B - Jovem; C e D - Imaturo; E - Adulto. 
No total foram amostradas 6.200 plântulas, 1.505 estipes e 409 touceiras de Euterpe oleracea. A população apresentou plantas (plântulas e estipes) e touceiras distribuídas em todos os estádios ontogenéticos caracterizados, ou seja, plântula, jovem, imaturo e adulto, sugerindo que a espécie neste local, apresenta um bom potencial de regeneração. Tais condições são favoráveis e prioritárias ao manejo sustentável da espécie.

Dentro dos estádios ontogenéticos, estimou-se uma distribuição por hectare de 6200 plantas no estádio de Plântula, 557 no estádio Jovem, 419 no estádio Imaturo I, 336 no estádio Imaturo II e 193 no estádio Adulto (Tabela 3). O número de plantas nesses estágios ontogenéticos se apresentou distribuído desigualmente, com um maior número de plantas nos estádios de crescimento inicial da espécie e com poucas plantas contribuindo com a maior parte da biomassa da população (Figura 5). Esta desigualdade na quantidade de plantas entre os estádios de desenvolvimento da espécie é coerente com os resultados apresentados para Euterpe edulis e outras espécies arbóreas estudadas (Silva, 1991; Reis, 1996; Tonetti, 1997; Fisch, 1998; Dancinguer, 1996; Alves 2000).

Tabela 3 - Número de plantas e touceiras de Euterpe oleracea verificados por estádios ontogenéticos e seus respectivos índices de Morizita, na ECFPn, município de Melgaço-PA.

\begin{tabular}{lcccc}
\hline \multicolumn{1}{c}{$\begin{array}{c}\text { Estádios } \\
\text { Ontogenéticos }\end{array}$} & № plantas/ha & Índice de Morizita & № touceiras/ha & Índice de Morizita \\
\hline Plântulas & 6200 & 2,92 & - & - \\
Jovem & 557 & 1,32 & 81 & 1,88 \\
Imaturo I & 419 & 1,15 & 98 & 1,14 \\
Imaturo II & 336 & 1,07 & 121 & 1,09 \\
Adulto & 193 & 1,80 & 109 & 1,18 \\
\hline
\end{tabular}


A utilização de características quantitativas tem auxiliado na definição de estádios ontogenéticos em alguns trabalhos com populações arbóreas (Silva, 1991; Carvalho, 1994; Dancinguer, 1996). Apesar de ter havido uma forte relação entre as características morfológicas, com a altura dos estipes e o número de folhas, observamos sobreposição de tamanho e número de folhas entre os estádios, possivelmente, devido a estas duas variáveis serem bastante influenciadas por fatores ambientais. Isso indica que apenas o tamanho não seria suficiente para caracterizar os estádios em E. oleracea. Já que, a idade fisiológica pode diferir entre indivíduos de uma mesma idade cronológica (Gatsuk et al., 1980).

Os estipes caracterizados como Imaturo II foram definidos por possuírem uma altura total mínima igual àquela apresentada pelos estipes adultos. No entanto, estes não foram caracterizados como tal, devido ao curto período de tempo no campo não ser suficiente para acompanhar a fenologia da espécie, considerando o estádio Imaturo II com potencial de reprodução.

A curva de densidade das plantas na população (Figura 5) mostra um grande número de plântulas e estipes no estádio jovem, representando $87,7 \%$ da população, caracterizando uma possível estratégia da espécie em manter sua população estruturada. Mantendo-se um grande número de plantas nos estádios menores de desenvolvimento, o que torna possível a reposição dos estipes nos estádios subsequentes aos que são mortos, garantindo-se portanto, estipes em todos os estádios de desenvolvimento da população. O estádio imaturo representa $9,8 \%$ da população com potencial reprodutivo, e a população reprodutiva, formada pelos adultos, representam apenas 2,5\%. O estádio adulto é responsável pela manutenção anual do banco de plântulas, o que possibilita o recrutamento dos estipes para os estádios superiores.

Das 409 touceiras amostradas na área de estudo, 81 estão no estádio Jovem, 36 Imaturo I, 183 Imaturo II e 109 Adultas (Tabela 3 ).

Com base neste levantamento, verifica-se que o maior número de touceiras encontram-se nos estádios maduros de desenvolvimento: Imaturo II e Adulto. Isto se deve ao fato de que a grande maioria das touceiras nesta área apresentam estipes maiores que $6 \mathrm{~m}$ de altura e/ou com sinal de reprodução (Figura 6). Os estádios ontogenéticos 
anteriores a estes dois últimos representam um estoque de touceiras "novas", que poderão ocupar o lugar das mais antigas com o avanço da maturidade.

Estudos considerando os estádios de tamanho, baseados nas alterações dos caracteres morfológicos dentro de cada estádio, indicam a capacidade de desenvolvimento do indivíduo em diferentes fases de seu crescimento. Com estes estudos é possível também, avaliar as causas da mortalidade dessa espécie nos diferentes estádios e no recrutamento de um estádio para o seguinte. Informações como essas podem ser utilizadas para o manejo de E. oleracea em florestas naturais.

Com base nos resultados obtidos, a curva de densidade das plantas por estádios ontogenéticos apresentou-se na forma de um $\mathrm{J}$ invertido, enquanto que, para as touceiras esta curva apresentou-se quase como uma reta crescente, caracterizando um maior número de touceiras adultas.

Esta diferença entre a forma como estipes e touceiras estão estruturados na população, reflete nas práticas silviculturais que devem ser adotadas para o manejo da espécie. Logo, o manejo sustentável para o açaizeiro deve ser conduzido a partir do corte apenas dos estipes adultos, desde que, em cada touceira seja mantido no mínimo um estipe adulto reprodutivo para a reprodução da espécie, o que manterá a estrutura genética da população.

Visto que, como as touceiras estão concentradas em maior número nos estádios adultos, o manejo não seria sustentável se fosse realizado por indivíduo, ou seja, o corte de todos os estipes na touça. O que provavelmente ocasionaria a perda de diversidade genética na população e reduziria o espaçamento adequado entre as touceiras. 


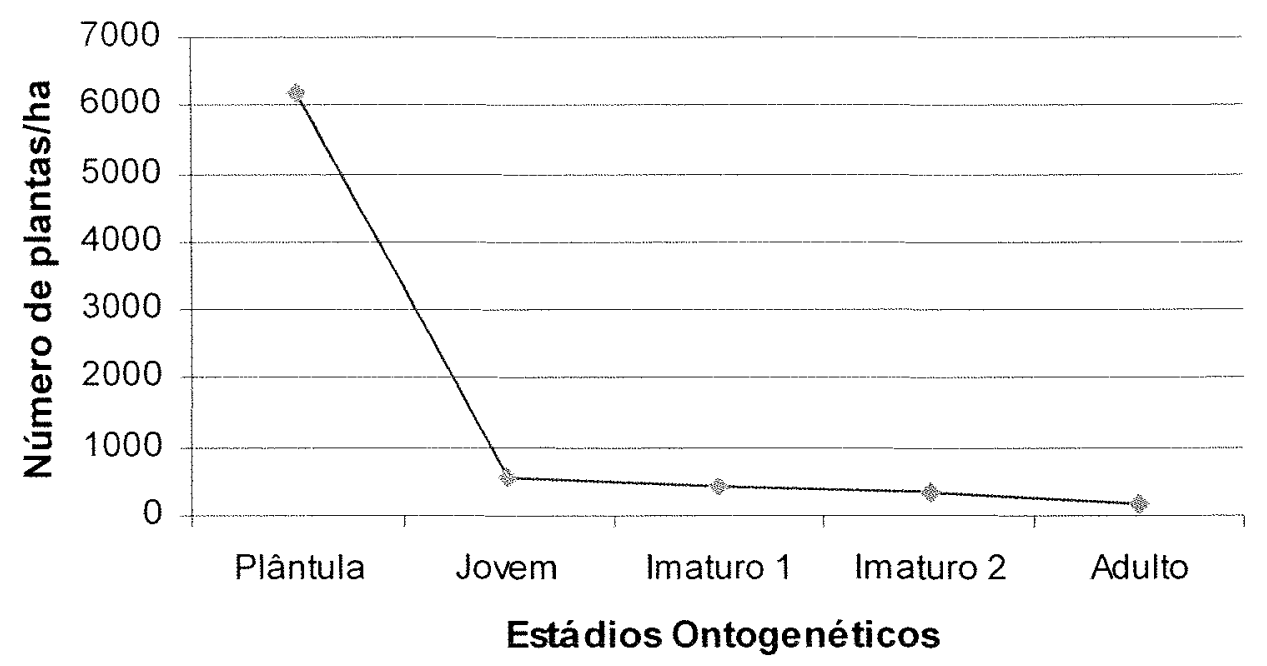

Figura 5 - Número total de plantas em cada estádio ontogenético, em uma população natural de Euterpe oleracea Mart., na ECFPn, município de Melgaço-PA.

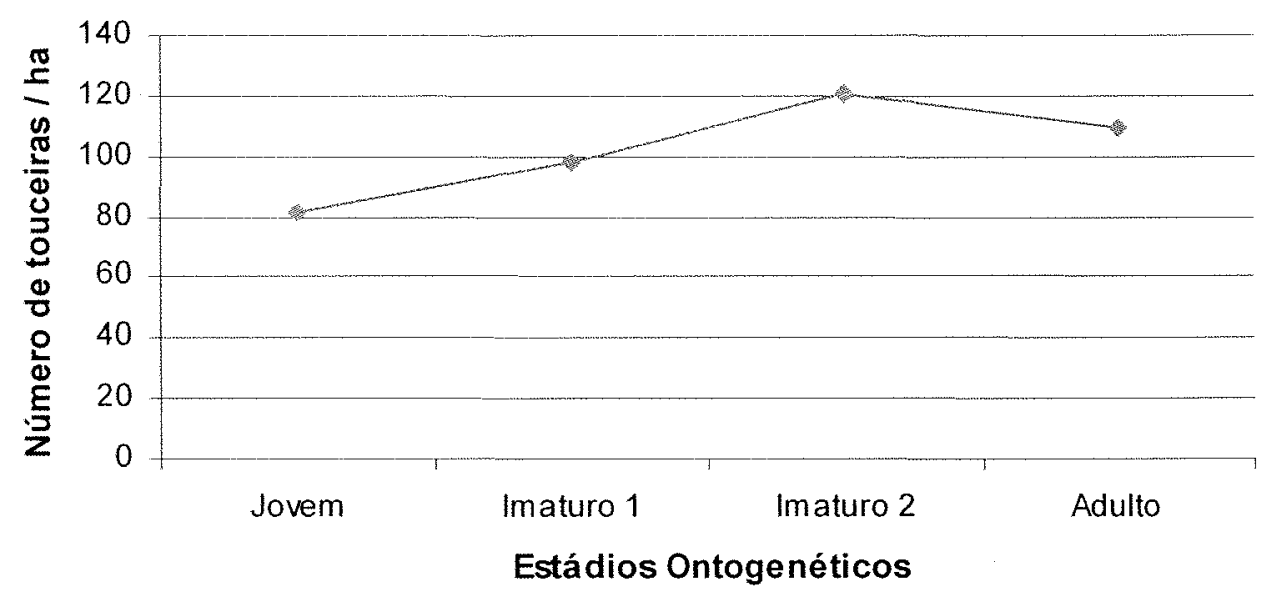

Figura 6 - Número total de touceiras por estádio ontogenético, em uma população natural de Euterpe oleracea Mart., na ECFPn, município de Melgaço-PA. 


\subsection{Estrutura de população}

Para caracterizar a estrutura de tamanho da população, as plantas (plântulas e estipes) e touceiras de Euterpe oleracea foram distribuídas em 12 classes de altura.

Devido à diferença do número de plantas e touceiras nestas classes, o resultado foi uma distribuição de tamanhos em forma de $\mathrm{J}$ invertido, com muitas plantas e touceiras pequenas e poucas grandes. Esta desigualdade de tamanhos é caracterizada como hierarquia de tamanhos (Weiner \& Solbrig, 1984).

A classe de tamanho com maior número de plantas foi a primeira $(45,6 \%$ do total), que abrange os estádios iniciais do desenvolvimento da palmeira: plântula e jovem. Apesar da redução do número de plantas da primeira classe para as demais, é possível observar que as classes posteriores ainda são numerosas, mesmo com a tendência decrescente da curva (Figura 7).

Para as touceiras, os estádios Jovem e Imaturo I (179 touceiras/ha) estão concentrados nas três primeiras classes de altura, enquanto que os estádios mais desenvolvidos (Imaturo II e Adulto) e numerosos (230 touceiras/ha) estão distribuídos de forma menos concentrada em nove classes de tamanho (Figura 8).

A ocorrência de estruturas de tamanho do tipo $\mathrm{J}$ invertido (distribuição exponencial negativa), com predominância de indivíduos nas classes menores e poucos nas maiores, é comumente associada a espécies com alta capacidade regenerativa, tolerantes à sombra e pertencentes à floresta primária (Whitmore, 1984). Na maioria das populações de espécies tropicais, as classes menores de desenvolvimento das plantas são as que apresentam maiores taxas de mortalidade (Solbrig, 1981); as causas geralmente são a presença de patógenos ou herbívoros e a competição entre plântulas ou entre plântulas e adultos (Swaine et al., 1987; Howe, 1990).

A tendência decrescente da curva para $E$. oleracea é provavelmente devido aos grandes índices de mortalidade nos primeiros estádios de vida da planta, principalmente pelas injúrias mecânicas, como queda de galhos e folhas da própria palmeira, bem como devido à inundação periódica da área. Não pode ser descartada a hipótese de ataque de patógenos e herbívoro, mesmo porque não foi realizado este tipo de levantamento no 
presente trabalho. É possível que estudos mais detalhados, como o levantamento florístico das espécies arbóreas encontradas junta às populações de E. oleracea, possam detectar níveis de competição intra e interespecíficas, que favoreçam o desenvolvimento desta espécie.

A estrutura de tamanho do tipo $\mathrm{J}$ invertido apresentado pelas plantas de E.oleracea deve ser de ocorrência geral no gênero Euterpe, pois estudos realizados com E. edulis mostraram esta mesma distribuição de tamanho nas populações (Silva, 1991; Reis, 1996; Tonetti, 1997; Fisch, 1998).

Esse padrão apresentado pode indicar, que esta população estudada se encontra estabilizada. Porém, isto não significa que eventuais processos como alterações nos eventos reprodutivos, grandes inundações nas áreas e ataques de patógenos e herbívoros, não implicariam em mudanças nesta estrutura populacional.

O padrão espacial dos estádios ontogenéticos das plantas calculado através do índice de Morizita (Tabela 3), foi agrupado para o estádio de plântula e aleatório para todos os estádios de desenvolvimento superiores ao de plântula, ou seja, jovem, imaturo e adulto. Igualmente, o padrão espacial para todos os estágios ontogenéticos das touceiras foi aleatório.

Diferentes causas podem determinar o padrão espacial dos estádios ontogenéticos, tais como: fatores ambientais e/ou bióticos, a densidade das sementes dispersadas, a capacidade de sobrevivência das plântulas, a influência de fatores de mortalidade e as interações intra e interespecíficas (Janzen, 1970; Hubbell, 1980; Hutchings, 1986).

A área de estudo apresentou variações ambientais que podem exercer influência sobre o padrão espacial dos estádios na população. O estádio de plântula, possivelmente, sofreu uma maior influência das variações ambientais na área, visto que, em $56 \%$ das parcelas que foram instaladas para serem feitas as mensurações das plântulas, não foi possível realizar as mensurações, devido à inundação das parcelas, conseqüência do período chuvoso de coleta dos dados. Porém, a aleatoriedade do padrão espacial encontrado pelos estádios Jovem, Imaturo e Adulto, sugere que estes estádios estejam menos sujeitos à ação dos fatores ambientais. 


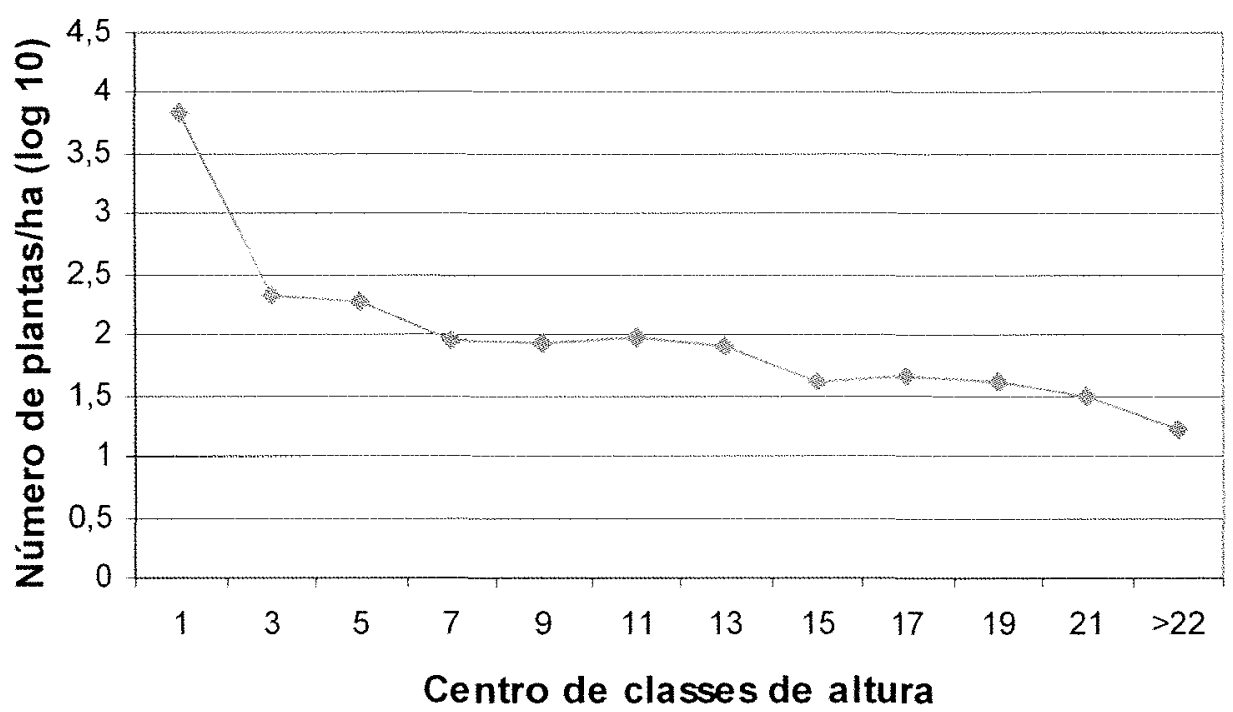

Figura 7 - Número de plantas (plântulas e estipes) por classes de altura $(\mathrm{m})$ de Euterpe oleracea Mart., na ECFPn, município de Melgaço-PA.

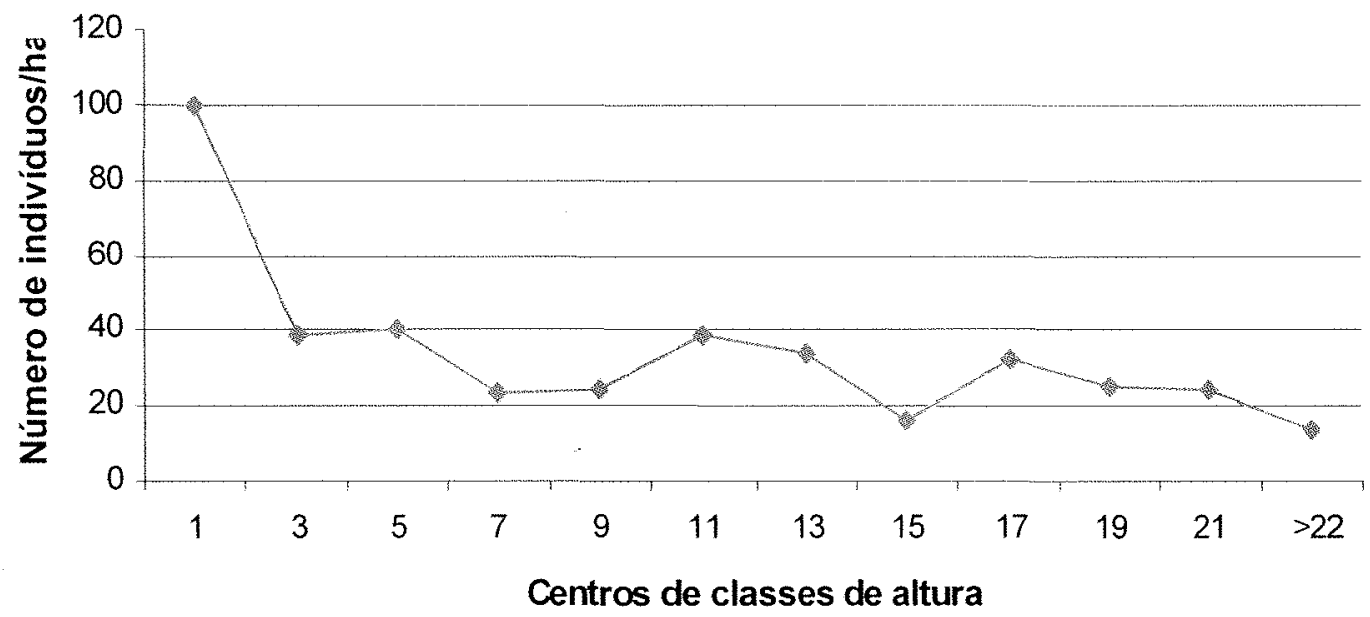

Figura 8 - Número de touceiras por classes de altura (m) de Euterpe oleracea Mart., na ECFPn, município de Melgaço-PA. 
O padrão espacial de uma população também é dependente da densidade de sementes dispersadas e da probabilidade de sobrevivência das plântulas (Janzen, 1970). Existem dois modelos que tentam explicar a distribuição das espécies arbóreas nas florestas tropicais: o modelo de Janzen (1970) e o modelo de Hubbell (1980). O primeiro sugere que a alta densidade de sementes próximo a planta-mãe aumenta a mortalidade das plântulas devido à predação de sementes e herbivoria, sugerindo uma distribuição não agrupada para a maioria das espécies tropicais. Já o segundo modelo sugere que, mesmo com alta mortalidade de plântulas próxima a planta-mãe, a porcentagem de sobreviventes ainda é maior que aquelas distantes da matriz., devido ao grande número de sementes lançadas ao solo.

O segundo modelo proposto poderia explicar o padrão agrupado do estádio de plântula. Visto que, após o amadurecimento dos frutos estes caem próximos às suas plantas-mãe, quando não são predados e/ou dispersados, ocasionando provavelmente o agrupamento de plântulas próximas às suas matrizes. Um estudo mais específico, envolvendo a estimativa de parentesco entre as plântulas e suas possíveis progenitoras, poderia determinar se aquelas estão realmente agrupadas próximas às suas mães.

Segundo Jardim (1995), a dispersão dos frutos e sementes da espécie E.oleracea é feita a curtas distâncias por pequenos animais roedores e a longas distâncias por tucanos, jacús, araçarís, periquitos, papagaios e sabiás. Desta forma, a distribuição aleatória dos estádios ontogenéticos superiores aos de plântula, na área de estudo, também está relacionada à distância percorrida pelos agentes dispersores, que facilitam o arranjo espacial das plantas de forma não agrupada.

As causas de mortalidade durante o estádio ontogenético de plântula não foi evidenciado, até mesmo porque o trabalho não tinha como objetivo essas informações. Mas, foi possível observar que os impactos mecânicos, provocados pelas quedas de folhas da própria espécie e de galhos ou árvores de outras espécies, contribuem com a mortalidade das plântulas.

Reis et al. (1996), estudando o padrão espacial de uma população de E. edulis em Blumenau -SC, encontrou um padrão agregado para o banco de Plântulas e aleatório para 
os estádios Adultos, Imaturos I e II. Apesar de serem diferentes os critérios usados para a distinção dos estádios, os resultados são similares para E.oleracea.

Esses resultados indicam que as espécies E.edulis e E.oleracea apresentam uma estrutura populacional muito similar, apesar de se diferenciarem quanto ao hábito de perfilhamento, com populações estruturadas na forma de $J$ invertido e os estádios de tamanho superiores ao de plântula com um padrão espacial aleatório.

Porém, o manejo sustentável da espécie E.edulis é realizado com um certo risco de perda de diversidade genética, visto que, o corte de um estipe resulta na perda do indivíduo. No entanto, o manejo sustentável da espécie E.oleracea não apresenta este problema, por não haver a retirada do indivíduo com o corte de alguns estipes, dada a formação de touceiras mantendo a estrutura genética original da população, sem perda de diversidade genética. Logo, só haveria perda se a exploração fosse muito intensa e com isso causasse a morte da touceira.

\subsection{Variabilidade genética}

Os resultados obtidos com base nos 05 locos de microssatélite analisados mostram que a população apresentou alta riqueza alélica, isto é, alto número de alelos por loco $(A)$, tanto para adultos quanto para progênies $(13,6$ e 13,4 , respectivamente) (Tabela 4).

A diversidade gênica $(H e)$ foi alta para adultos $(0,839)$ e plântulas $(0,844)$. Assim como, a heterozigosidade observada $(H o)$ também foi alta. Porém, esta foi menor para os adultos $(0,709)$ em relação as plântulas $(0,822)$. De forma geral, as estimativas médias obtidas para He foram superiores as de Ho, principalmente para as plantas adultas, revelando excesso de indivíduos homozigotos na população, refletindo em um alto índice de fixação médio encontrado para os adultos

$O$ índice de fixação de Wright $(f)$ mede a redução da heterozigosidade em relação ao esperado, para uma população panmítica. Quando os valores de $f$ são iguais a zero indicam que na população estão ocorrendo acasalamentos de forma aleatória e não há endogamia na população. Portanto, valores significativamente superiores a zero indicam 
excesso de indivíduos homozigotos na população, e valores negativos, excesso de heterozigotos.

Os indivíduos adultos, apresentaram of $f$ igual a 0,156 , este valor representam um excesso de homozigotos na população, indicando a existência de endogamia.

A riqueza alélica e a diversidade gênica apresentaram índices bastante expressivos, mostrando que é alta a variabilidade genética na população estudada de Euterpe oleracea. Esses resultados são importantes, pois as gerações posteriores poderão apresentar novos recombinantes que possibilitarão a manutenção da variabilidade genética existente e dinâmica populacional.

Tabela 4 - Índices de diversidade genética para adultos e plântulas de uma população natural de Euterpe oleracea, na ECFPn município de Melgaço-PA, obtidos a partir da análise de cinco locos microssatélites, sendo $A$ : número médio de alelos; $H e$ : diversidade genética; $H o$ : heterozigosidade observada e $f$ : índice de fixação de Whight .

\begin{tabular}{lcccc}
\hline \multicolumn{1}{c}{ População } & $\boldsymbol{A}$ & $\boldsymbol{H e}$ & Ho & $\boldsymbol{f}$ \\
\hline Adultos & 13,6 & 0,839 & 0,709 & 0,156 \\
Plântulas & 13,4 & 0,844 & 0,822 & 0,027 \\
Média & 13,5 & 0,842 & 0,766 & 0,091 \\
\hline
\end{tabular}

Os valores aqui apresentados são condizentes aos encontrados para outras espécies arbóreas tropicais, utilizando marcador microssatélite. Gaiotto (2001), com base em 18 locos de microssatélite para duas populações de Eutepe edulis de matas de galeria do Cerrado brasileiro, detectou níveis elevados de diversidade gênica e heterozigosidade observada média nas populações de 0,749 e 0,690 , respectivamente. Santos (2002) também estimou altas taxas de diversidade gênica média $(0,848)$ e heterozigosidade observada média $(0,833)$ para a espécie Hymenaea courbaril utilizando cinco locos microssatélites, para três populações na região do Pontal do Paranapanema. 
Os valores numericamente superiores aos encontradas para espécies arbóreas, estudadas através de marcadores isoenzimáticos, confirmam o elevado conteúdo de informação genética gerado pelos marcadores moleculares microssatélites.

Esses resultados são importantes para o manejo sustentável da espécie, de forma que, mesmo sendo uma espécie que perfilha, não significa que são dispensáveis os cuidados ao se manejar as touceiras. A exploração do palmito é realizada a partir do corte dos estipes adultos, portanto, mesmo que fiquem estipes imaturas e jovens nas touceiras estes provavelmente precisarão de relativamente longo período para alcançar o estádio reprodutivo, o que poderia favorecer a autofecundação em outras plantas da espécie, podendo resultar em aumento da endogamia e no aparecimento de genes deletérios em homozigose nos filhos.

\subsection{Sistema reprodutivo}

A taxa de cruzamento na população foi aferida através dos índices multilocos $(\mathrm{tm})$ e da média de locos únicos $(t s)$ (Tabela 5).

A estimativa de $t m$ obtida a partir de 9 famílias avaliadas na população foi de 1,000 , revelando que $100 \%$ das plântulas foram geradas por cruzamentos, o que faz com que E. oleracea seja uma espécie alógama.

Jardim (1991), a partir de estudos de biologia reprodutiva dessa espécie mostrou, através dos testes de sistema reprodutivo, que a proporção de frutos formados por xenogamia $(83,0 \%)$ eram significativamente superiores que os formados nos testes de gueitonogamia $(6,8 \%)$ e de autogamia $(7,16 \%)$. Isto caracteriza a espécie E. oleracea como predominantemente alógama, coerente com os resultados do presente estudo.

Ohashi (1990), estudando variações genéticas em caracteres morfológicos de populações naturais de E. oleracea, encontrou através da razão entre a variância fenotípica dentro de progênies e a variância entre progênies, que o sistema reprodutivo do açaizeiro era também preferencialmente de fecundação cruzada

A caracterização da taxa de cruzamento para o açaizeiro indica a alogamia como mecanismo básico de reprodução da espécie mas, com elevada probabilidade de gerarem 
irmãos germanos dentro de famílias de polinização aberta ( $r p$ de 0,594$)$. A estimativa obtida para $r p$ pode ser justificada com base nos resultados do teste de paternidade aqui apresentados. Tal teste indicou, um maior sucesso reprodutivo de alguns indivíduos na população, indicando que uma alta proporção de pólens de poucas plantas adultas cruzando ao mesmo tempo, podem resultar em progênies com alto grau de parentesco

A $t m$ igual a 1 sugere a inexistência de autofecundação $(s)$ na população estudada, uma vez que $t \mathrm{~m}+\mathrm{s}=1$. Entretanto, a diferença entre a taxa de cruzamento multilocos e unilocos (tm-ts igual a 0,129) indica a ocorrência de endogamia por acasalamento entre indivíduos aparentados.

Para a espécie E.edulis, os resultados de taxa de cruzamento foram similares, tanto utilizando marcadores isoenzimáticos (Reis et al, 1996), como marcadores microssatélites (Gaiotto, 2001), considerando a espécie como predominantemente alógama.

Tabela 5 - Estimativas de parâmetros de sistema reprodutivo, sendo $t m$ : taxa de cruzamento multiloco; $t s$ : taxa de cruzamento baseada na média de locos individuais; $r p$ : correlação de paternidade dentro de progênies resultantes de cruzamento e $r t$ : correlação entre taxas de cruzamento dentro de famílias.

\begin{tabular}{cc}
\hline PARAMETROS & ECFPn \\
\hline tm & $1,000(0,000)^{*}$ \\
ts & $0,871(0,038)$ \\
tm-ts & $0,129(0,038)$ \\
rp & $0,594(0,097)$ \\
rt & $0,457(0,000)$
\end{tabular}

* Entre parênteses: erro-padrão estimado através de 10.000 "bootstraps" 


\subsection{Fluxo gênico}

Foram analisadas 132 plântulas compondo 9 famílias da população, para o teste de paternidade por determinação direta. Destas 132 plântulas, apenas para 13 (9,8\% do total) foi encontrado o possível progenitor paterno na área amostral. Sendo que em 8 famílias, pelo menos para 1 indivíduo, foi possível determinar o possível pai (Tabela 6).

Como não foram encontrados os possíveis pais de $90,2 \%$ das plântulas, pode-se deduzir que a área representativa de $4.800 \mathrm{~m}^{2}$, na qual foi realizado o levantamento dos indivíduos adultos, provavelmente foi insuficiente para amostrar os possíveis pais e que esses, portanto, estão fora dos limites amostrados.

Com base nos resultados, verifica-se que na população de E. oleracea, os indivíduos D90, D106 e D107 foram identificados como os possíveis pais de mais de uma plântula, o que representa o sucesso reprodutivo superior aos demais indivíduos na população. Os indivíduos D106 e D107 fecundaram duas matrizes distintas.

Além disso, as distâncias entre os progenitores (maternos e paternos), dentro da área amostral, variaram de $6,20 \mathrm{~m}$ a $76,78 \mathrm{~m}$. Isso mostra que, por se tratar de análise de progênies provenientes de polinização aberta, a distância máxima do fluxo gênico direto para a população analisada é de $76,78 \mathrm{~m}$, considerando-se a distância entre os progenitores encontrados. Portanto, como apenas $9,8 \%$ das progênies tiveram seus possíveis pais determinados, pode ser considerado a existência de fecundação por pólen de indivíduos não amostrados e admitir que o fluxo gênico via pólen seja mais amplo do que foi detectado neste estudo. 
Tabela 6 - Prováveis progenitores paternos de Euterpe oleracea, com coincidência de $80 \%$ dos genes avaliados .

\begin{tabular}{ccc}
\hline Indivíduos (Plântulas) & Provável progenitor & Distância dos pais (m) \\
\hline D162.25 & D106 & $\mathbf{6 , 2 0}$ \\
\hline D173.10 & D125 & 40,47 \\
\hline D195.24 & D90 & $\mathbf{2 6 , 7 2}$ \\
D195.29 & D90 & $\mathbf{2 6 , 7 2}$ \\
\hline D201.10 & D106 & $\mathbf{1 9 , 2 4}$ \\
D201.12 & D102 & 19,54 \\
\hline D259.03 & D86 & 57,70 \\
D259.06 & D107 & $\mathbf{4 9 , 1 5}$ \\
D259.28 & D94 & 39,27 \\
\hline D292.14 & D104 & 61,76 \\
\hline D 293.19 & D91 & 71,64 \\
\hline D 317.09 & D107 & $\mathbf{7 6 , 7 8}$ \\
D317.11 & D107 & $\mathbf{7 6 , 7 8}$ \\
\hline
\end{tabular}

Jardim (1991) estudou uma população de E. oleracea na llha do Cumbu, Município de Acará - PA. A espécie apresentou variações na sazonalidade de floração em relação ao período chuvoso e seco, que influenciaram na distância média efetiva entre touceiras florescendo. Nos meses de maior pico de floração da espécie (fevereiro-maio) a distância média entre as touceiras florescendo variou de $8,18 \mathrm{~m}$ a $8,78 \mathrm{~m}$ e nos meses de menor floração (julho-outubro) variou de $13,60 \mathrm{~m}$ a $18,47 \mathrm{~m}$. Isto mostra que existe um maior número de touceiras em floração no período chuvoso, com menor espaçamento entre elas, assim como, um menor número de touceiras em floração no período seco, associado a um maior espaçamento entre a mesmas.

A partir destes resultados, é possível considerar que os eventos fenológicos do açaizeiro estão diretamente associados aos períodos chuvosos e secos, assim como aos padrões de polinização e dispersão (Jardim, 1991). Portanto, é possível que os vetores de polinização sejam específicos ou variem seu comportamento para cada época de floração, 
sendo de curto e longo alcance de vôo devido às variações nas distâncias efetivas entre touceiras.

As sementes coletadas para o presente estudo foram oriundas do período de menor floração da espécie, no qual as touceiras em floração encontram-se mais distantes uma das outras, afetando efetivamente o comportamento do polinizador e o fluxo gênico.

Possivelmente, a caracterização do fluxo gênico na população estudada foi influenciado pela sazonalidade de floração da espécie, podendo ser encontrado um maior número de possíveis pais, se as sementes tivessem sido coletadas na época de pico de floração da espécie, já que a distância entre as touceiras em floração seria menor.

Reis (1995) determinou o fluxo gênico indireto em algumas populações naturais de palmiteiro, utilizando marcadores isoenzimáticos, encontrando uma distância de transporte do pólen, em média, de $56 \mathrm{~m}$. Mesmo que as metodologias tenham sido diferentes entre este trabalho e o de Reis (1995), os valores poderiam ser associados e çaracterizar o fluxo gênico para o gênero Euterpe como sendo à curta distância.

Portanto, com estes resultados é possível que sejam direcionadas medidas para o manejo sustentável, referente a se manter distâncias pequenas entre touceiras, devido ao fluxo gênico via pólen detectado ser provavelmente a curta distância. 


\section{CONCLUSÕES}

Para a população de Euterpe oleracea foi possível distinguir quatro estádios ontogenéticos, sendo que estes revelaram características particulares dos indivíduos neles presentes.

A estrutura de tamanho apresentada pela população foi do tipo $J$ invertido. Esta curva, característica de espécies que formam banco de plântulas, deveu-se principalmente ao maior número de plantas e touceiras nas menores classes de tamanho e poucas nas maiores classes. Este padrão indica que a população estudada se encontra estabilizada.

O padrão espacial das plantas e touceiras, em cada um dos seus estádios ontogenéticos, mostrou que as plântulas encontram-se agrupadas e os demais estádios distribuídos de forma aleatória.

A alta riqueza alélica e os altos índices de heterozigosidade caracterizam uma alta variabilidade genética na população de E.oleracea.

Os resultados obtidos na estimativa da taxa de cruzamento indicaram ser a população de E. oleracea alógama, porém, com 12,9\% de cruzamento entre indivíduos aparentados. Devido ao fluxo gênico, medido de forma direta, ocorrer a curta distância, pressupõe-se que indivíduos aparentados, provavelmente, estejam mais próximos um dos outros. Porém, seriam necessários estudos de distribuição genética para afirmação mais segura.

Para o manejo sustentável da espécie deve-se manter pelo menos um estipe reprodutivo em cada touceira, para que seja mantido um espaçamento adequado entre indivíduos para viabilizar o fluxo gênico. 


\section{REFERÊNCIAS BIBLIOGRÁFICAS}

AGREN, J.; ZACCKRISSON, O. Age and structure of Pinus sylvestris populations on mires in central and northern Sweden. Journal of Ecology, v.78, p.1049-1062, 1990.

ALMEIDA, S.S.; LISBOA, P.L.B.; SILVA, A.S.L. Diversidade florística de uma comunidade arbórea na Estação Científica "Ferreira Penna", em Caxiuanã-PA. Boletim do Museu Paraense Emílio Goeldi. Série Botânica, v.9, p.93-128, 1983.

ALVES, L.F. Competição intraespecífica e padrão espacial em uma população de Euterpe edulis Mart. (Arecaceae). Campinas, 1994. 67p. Dissertação (M.S.) - Instituto de Biologia, Universidade Estadual de Campinas.

ALVES, L.F. Estrutura, dinâmica e alometria de quatro espécies arbóreas tropicais. Campinas, 2000. 87p. Tese (Doutorado) - Universidade Estadual de Campinas.

ALVES, R.N.B. Diagnóstico da agropecuária amapaense. Macapá: EMBRAPA/CPFAF, 1992. 44p.

ASHLEY, M.V.; DOW, B.D. The use of microsatelites for genetic of natural populations. In: SCHIERWATER, B.; STREIT, B.; WAGNER, G.P., et al. (Ed.). Molecular ecology and evolution: approaches and applications. Basel: Birkhauser Verlag, 1994. p.185-201.

BASSAM, B.J.; CAETANO-ANOLLES, G.; GRESSHOFF, P.M. Fast and Sensitive Silver Staining of DNA in Polyacrylamide Gels. Analytical Biochemistry. v.196, p. 80-83, 1991.

BAWA, K.S. Breeding systems of tree species of a lowland tropical community. Evolution, v.28, p. 85-92, 1974.

BAWA, K.S. Mating systems, genetic differentiation and speciation in tropical rain forest trees. Biotropica, v.24, n.2b, p.250-255, 1992. 
BOVI, M.L.A. Pesquisas em desenvolvimento com o açaizeiro no Instituto Agronômico. Agronômico, v.36, n.2, p.155-178, 1984.

BOVI, M.L.A.; DIAS, G.; GODOY JÚNIOR, G. Biologia Floral do Açaizeiro (Euterpe oleracea Mart.). In: CONGRESSO DA SOCIEDADE BOTÂNICA DE SÃO PAULO, 6., São Paulo, 1986. Anais. São Paulo: UNICAMP, 1986. p.91.

BOVI, M.L.A.; GODOY JÚNIOR, G.; SÁES, L.A. Pesquisas com os gêneros Euterpe e Bactris no Instituto Agronômico de Campinas. Agronômico, v.39, n.2, p.129-174, 1987.

BRASIL. Ministério da Agricultura. Portaria n ${ }^{0}$ 78, de 17 de março de 1998. Diário Oficial, n.52, Seção 1, p.38-40. mar.1998.

BRONDANI, R.P.V.; BRONDANI, C.; TARCHINI, R.; et al. Development, characterization and mapping of microsatellite markers in Eucalyptus grandes and E. urophylla. Theoretical and Applied Geneties, v.97, p.816-827, 1998.

BROWN, A.H.D.; WEIR, B.S. Measuring genetic variability in plant populations. In: TANKSLEY, S.D.; ORTON, T.J. (Ed.) Isozymes in plant genetics and breeding. Part A. Amsterdam: Elsevier Science, , 1983. p.219-239.

BROWN, A.H.D. Genetic characterization of plant mating systems. In: BROWN A.H.D.; CLEGG, M.T.; KAHLER, A.L.; et al. (Ed.). Plant population genetics, breeding and genetic resources. Suderland: Sinauer Associates, 1990. p.145-162.

CALDATO, S.L.; LONGHI, S.J.; FLOSS, P.A. Estrutura populacional de Ocotea porosa (Lauraceae) em uma floresta ombrófila mista, em Caçador (SC). Ciência Florestal, v.9, n.1, p. 89-101, 1999.

CALZAVARA, B.B.G. As possibilidades do açaizeiro no Estuário Amazônico. Boletim da Faculdade de Ciências Agrárias do Pará. v.5. p.1-103. 1972.

CALZAVARA, B.B.G. Açaizeiro: recomendações básicas. Belém: EMBRAPA, CPATU, 1987. 6p.

CARVALHO, R.M. Aspectos da história de vida de folhas do palmiteiro (Euterpe edulis Mart., Arecaceae). Campinas, 1994. 86p. Dissertação (M.S.) - Instituto de Biologia, Universidade Estadual de Campinas. 
CAVALCANTE, P.B. Frutas comestíveis da Amazônia. 5.ed. Belém: CEJUP, 1991. $279 \mathrm{p}$.

CHASE, M.R.; MOLLER, C.; KESSELI, R.; BAWA, K.S. Long distance gene flow in a fragmented tropical tree population. Nature, v.123, p.127-132, 1996.

CIAMPI, A.Y. Desenvolvimento e utilização de marcadores microsatélites, AFLP e sequenciamento de cpDNA, no estudo da estrutura genética e parentesco em populações de copaiba (Copaifera langsdorffii) em matas de galeria no cerrado. Botucatu, 1999. 204p. Tese (Doutorado) -Instituto de Biociências. Universidade Estadual Paulista "Julio de mesquita Filho".

CONDIT, R; HUBBELL, S.P. Abundance and DNA sequence of two-base repeat regions in tropical tree genomes. Genome, v.34, p.66-71, 1991.

COSTA, D.C.T. Análise dos processos de extração e beneficiamento do palmito de açaizeiro (Euterpe oleracea Mart.) em áreas ribeirinhas do município de Breves, Estado do Pará, Brasil. Belém, 2000. 72p. Dissertação (M.S.) - Faculdade de Ciências Agrárias do Pará.

DANCIGUER, L. Aspectos da regeneração de duas espécies arbóreas em um fragmento florestal do sudeste brasileiro. Campinas, 1996. 67p. Dissertação (M.S.) - Instituto de Biologia, Universidade Estadual de Campinas.

DOW, B.D.; ASHLEY, M.V. Microsatellite analysis of seed dispersal and parentage of saplings in bur oak, Quercus macrocarpa. Molecular Ecology, v.5, p.615-627, 1996.

DOW, B.D.; ASHLEY, M.V.; HOWE, H.F. Characterization of highly variable $(\mathrm{AG} / \mathrm{CT}) \mathrm{N}$ microsatellite in the bur oak, Quercus macrocarpa. Theoretical and Applied Genetics, v.91, p.137-141, 1995.

EGUIARTE, L.E.; PEREZ-NASSER, N.; PIÑERO, D. Genetic structure, outcrossing rate and heterosis in Astrocarium mexicanum (tropical palm): implications for evolution and conservation. Heredity, v.69, p.217-228, 1992.

FAO. Forest resources assesment 1990: tropical countries. Rome: 1993. (FAO. Forestry Paper, 112).

FERREIRA, M.E.; GRATTAPAGLIA, D. Introdução ao uso de marcadores RAPD e RFLP em análise genética, CENARGEM, Brasília: EMBRAPA 1995. 220p. 
FISCH, S.T.V. Dinâmica de Euterpe edulis Mart. na floresta ombrófila densa Atlântica em Pindamonhangaba - SP. São Paulo, 1998. 126p. Tese (Doutorado) - Instituto de Biociência, Universidade de São Paulo.

FRANKEL, O.H.; BROWN, A.H.D.; BURDON, J.J. The conservation of plant biodiversity. Cambridge: Cambridge University Press, 1996. 299p.

FUTUYMA, D.J. Biologia evolutiva. Ribeirão Preto: Sociedade Brasileira de Genética, $1992,631 \mathrm{p}$.

GAIOTTO, F.A. Inferências sobre herança quantitativa e estrutura genética em populações naturais de Euterpe edulis Mart. Utilizando marcadores microsatélites. Piracicaba, 2001. 122p. Tese (Doutorado) - Escola Superior de Agricultura "Luiz de Queiroz". Universidade de São Paulo.

GAIOTTO, F.A.; BRONDANI, R.P.V.; GRATTAPAGLIA, D. Microsatellite markers for heart of palm - Euterpe edulis and Euterpe oleracea Mart. (Arecaceae). Molecular Ecology Notes, v.1, n.1, p.86-88, 2001.

GANDARA, F.B. Diversidade genética, taxa de cruzamento e estrutura espacial dos genótipos em uma população de Cedrela fissilis Vell. (Meliaceae). Campinas, 1996. 70p. Dissertação (M.S.) -Instituto de Biologia, Universidade Estadual de Campinas.

GATSUK, E.; SMIRNOVA, O. V.; VORONTZOVA, L.I.; et al. Age states of plants of various growth forms. Journal of Ecology, v.68, p.675-96. 1980.

GRATTAPAGLIA, D.; CIAMPI, A.Y.; GAIOTTO, F.A.; et al. DNA technologies for forest tree breeding and conservation. In: INTERNATIONAL FOUNDATION FOR SCIENCE WORKSHOP, Florianópolis, 1998. Recent advances in biotechnology for tree conservation and management. proceedings. Florianópolis: 1998. p.50-61. GREIG-SMITH, P. Quantitative plant ecology. 3.ed. London: Blackwell Scientific 1983. 359p.

HALL, P.; ORREL, L.C.; BAWA, K. Genetic diversity and mating system in a tropical tree, Carapa guianensis (Meliaceae). American Journal of Botany, v.81, n.9, p.1104-1111, 1994. 
HALLE, F.; OLDEMAN, R.A.A.; TOMLINSON, P.B. Tropical tress and forests: an architectural analysis. New York: Springer-Verlag, 1978. 441p.

HAMRICK, J.L. The distribuition of genetic variation whitir and among natural forest population. In: SHONEWALD-COX, C.M.; CHAMBERS, S.M.; MACBIDE, B.; THOMAS, W.L. (Ed.). Genetic and conservation. New York: The Benjamim Puse., 1983. p.335-348.

HAMRICK, J.L.; GODT, M.J.W. Allozyme diversity in plant species. In: BROWN, A.H.D.; ClEGG, M.T.; KAHLER, A.L.; et al. (Ed.). Plant population genetics, breeding and genetic resources. Sunderland. Sinauer, 1990. p.43-63.

HAMRICK, J.L.; MURAWSKY, D.A.. The breeding structure of tropical tree populations. Plant Species Biology, v.5, p.157-165, 1990.

HARPER, J.L. Population biology of plants. London: Academic Press, 1977. 829p.

HUBBELL, S.P. Seed predation and coexistence of tree species in tropical forests. Oikos, v.35, p.214-229, 1980.

HUBBELL, S.P.; FOSTER, R..B. La estructura espacial en gran escala de un bosque neotropical. Revista de Biologia Tropical, v.35, Supl. 1, p.7-22, 1987.

HUTCHINGS, M.J. The structure of plant populations. In: CRAWLEY, M.J. (Ed.) Plant ecology. 2.ed. Oxford: Blackwell Science, 1986. p.97-136.

HOWE. H.F. Survival and growth of juvenile Virola surinamensis in Panama: effects of herbivory and canopy closure. Journal of Tropical Ecology, v.6, p.259-280, 1990.

INSTITUTO BRASILEIRO DE GEOGRAFIA E ESTATÍSTICA. Produção da Extração Vegetal e da Silvicultura, Rio de Janeiro, 1995. 277p.

JANZEN, D. H. Herbivores and the number of tree species in tropical forests. American Naturalist, v.104, p.501-528. 1970

JARDIM, M.A.G. Aspectos da biologia reprodutiva de uma população natural de açaizeiro (Euterpe oleracea Mart.) no Estuário Amazônico. Piracicaba, 1991. 90p. Dissertação (Mestrado) - Escola Superior de Agricultura "Luiz de Queiroz", Universidade de São Paulo.

JARDIM, M.A.G. Cartilha informativa sobre palmeira açai (Euterpe oleracea Mart.). Belém: Museu Paraense Emílio Goeldi, 1995. 11 p. 
JARDIM, M.A.G.; ANDERSON, A.B. Manejo de populações nativas de açaizeiro no Estuário Amazônico, resultados preliminares. Boletim de Pesquisa Florestal, v.15, p.1-18, dez.1987.

JARDIM, M.A.G.; ROMBOLD, J.S. Effects of adubation and thinning on açaí palm (Euterpe oleracea Mart.) fruit yield from a natural population. Boletim do Museu Paraense Emílio Goeldi, v.10, n.2, p.283-293, 1994.

JARNE, P.; LAGODA, P.J.L. Microsatellites, from molecules to population and back. Tree, v.11, n.10, p.424-429, 1996.

KAGEYAMA, P.Y. Conservação "in situ" de recursos genéticos de plantas. IPEF, n.35, p.7-37, 1987.

KAGEYAMA, P.Y. Genetic structure of tropical tree species of Brazil. In: BAWA, K.S.; HADLEY, M. (Ed). Reproductive ecology of tropical forest plants. Paris: UNESCO; The Parthenon Publishing Group, 1990. p.375-387.

KAGEYAMA, P.Y.; GANDARA, F.B.; VENCOVSKY, R. Conservação in situ de espécies arbóreas tropicais. In: NASS, L.L.; VALOIS, A.C.C.; MELO, I.S.; et al. Recursos genéticos e melhoramento de plantas. Rondópolis: Fundação MT, 2001. cap.7, p.150-158.

KREBS, C.J. Ecological methodology. New York: Harper \& Row, 1989. 654p.

LEWIS, P.O.; ZAYKIN, D. Genetic data analysis: computer program for the analysis of allelic data: Version 1.0 (d15). Free program distributed by the authors over the internet from the GDA Home Page at http://alleyn.eeb.uconn.edu/gda/, 2002.

LITT, M.; LUTY, J.A. A hypervariable microssatellite revealed by in vitron ampliffication of a dinucleotide repead within the cardiac muscle actin gene. American Journal of Human Genetics, v.44, p.397-401. 1989.

LOVELESS. M.D.; HAMRICK, J.L. Ecological determinants of genetic structure in plant populations. Annual Review Ecology Systematics, v.15, p.65-95, 1984. 
MARQUES, M.C.M.; JOLY, C.A. Estrutura e dinâmica de uma população de Calophyllum brasiliense Camb. em floresta higrófila do sudeste do Brasil. Revista Brasileira de Botânica, v.23, n.1, p.107-112, mar.2000.

MARTINI, A.M.Z. Estrutura e dinâmica populacional de três espécies arbóreas tropicais. Campinas, 1996. 96p. Dissertação (M.S.) - Instituto de Biologia, Universidade Estadual de Campinas.

MARTINS, P.S. Estrutura populacional, fluxo gênico e conservação "in situ". IPEF, n. 35 , p. $71-78,1987$.

MESQUITA, S.A.J.; JARDIM, M.A.G. Avaliação das populações nativas de açaizeiro Euterpe oleracea na comunidade do Rio Marajoí, município de Gurupá (PA). Boletim do Museu Paraense Emílio Goeldi, v.12, n.2, p.265-269, 1996.

MORAN, G.F.; HOPPER, S.D. Genetic diversity and the insular population structure of the rare granite rock species, Eucalyptus caesia Benth. Australian Journal of Botany, v.31, p.161-172, 1987.

MOREIRA, D.A. Caracterização morfológica, crescimento e produtividade de palmito de açaizeiro (Euterpe oleracea Mart.) na região nordeste paraense. Jaboticabal, 1998. 97p. Dissertação (M.S.) - Faculdade de Ciências Agrárias e Veterinárias, Universidade Estadual Paulista. "Julio de Mesquita".

MOURÃO,L. Açaizeiro: açaí e palmito no estuário amazônico. In: MOURÃO,L.; JARDIM, M.; GROSSMANN, M. (Org.). Açaí: possibilidades e limites em processos de desenvolvimento sustentável no estuário amazônico. Belém: CEGUP, 1999.

MYERS, N. Tropical forests and their species: going, going...? In: WILSON, E.O. (Ed.)

Biodiversity. Washington: National Academic Press, 1988. p.21-27.

NEGRÃO, M.O. Estrutura genética de populações naturais de Syagrus romanzoffiana (Arecaceae) do continente (Serra do Mar, SP) e da Ilha dos Alcatrazes. Piracicaba, 1999. 78p. Dissertação (Mestrado) - Escola Superior de Agricultura "Luiz de Queiroz", Universidade de São Paulo.

NEI, M. Molecular evolutionary genetics. New York: Columbia University Press, 1987. 512p. 
NOGUEIRA, O.L. Regeneração, manejo e exploração de açaizais nativos de várzea do estuário amazônico. Belém, 1997. 149p. Tese (Doutorado) - Universidade Federal do Pará.

ODUM, E.P. Ecologia. Rio de Janeiro: Ed. Guanabara, 1988. 434p.

OHASHI, S.T. Variação genética em populações de açaizeiro (Euterpe oleracea Mart.) do Estuário Amazônico. Piracicaba, 1990. 119p. Dissertação (Mestrado) - Escola Superior de Agricultura "Luiz de Queiroz", Universidade de São Paulo.

OLIVEIRA, M.S.P. Avaliação do modo de reprodução e de caracteres quantitativos em 20 acessos de açaizeiro (Euterpe oleracea Mart.) em Belém - PA. Recife, 1995. 145p. Dissertação (M.S.) - Universidade Federal Rural de Pernambuco.

O'MALLEY, D.M.; BUCKLEY, D.P.; PRANCE, G.T.; et al. Genetics of Brazil nut (Bertholletia excelsa Humb \& Bonpl. Lecythidaceae). 2. Mating system. Theoretical and Applied Genetics, v.76, p.929-932, 1988.

OYAMA, K. Conservation biology of tropical tress: demographic and genetic considerations. Environment Update, v.1, p.17-32. 1993.

PERECIN, M.B. Diversidade genética em populações naturais de espécies de espinheirasanta, Maytenus aquifolia Mart. e M. ilicifolia Mart. ex Reiss. Piracicaba, 2000. 134p. Tese (Doutorado) - Escola Superior de Agricultura "Luiz de Queiroz", Universidade de São Paulo.

PIMENTA, J.A. Estudo populacional de Campomanesia xanthocarpa O.Berg (Myrtaceae) no Parque Estadual Mata dos Godoy, Londrina, PR. Campinas, 1998.96p. Tese (Doutorado) -Instituto de Biologia, Universidade Estadual de Campinas.

PIRES, J.M. Estudos dos principais tipos de vegetação do estuário do amazonas. Piracicaba, 1972. 183p. Tese (Doutorado) - Escola Superior de Agricultura "Luiz de Queiroz". Universidade de São Paulo.

PIRES-O'BRIEN, M.J.; O'BRIEN, C.M. Ecologia e modelamento de florestas tropicais. Belém: FCAP, Serviço de Documentação e Informação, 1995. 400p.

RAFALSKI, J.A.; VOGEL, J.M.; MORGANTE, M.; et al. Generating and using DNA markers in plants. In: BIRREN, B.; LAI, E. (Ed.) Nonmammalian genomic analysis: a practical guide. New York: Academic Press: New York, 1996. p.75-134. 
REIS, A. Dispersão de sementes de Euterpe edulis M. (Palmae) em uma floresta ombrófila densa montana da encosta atlântica em Blumenau, SC. Campinas, 1995. 154p. Tese (Doutorado) - Instituto de Biologia, Universidade Estadual de Campinas.

REIS, A.; KAGEYAMA, P.Y.; REIS, M.S.; et al. Demografia de Euterpe edulis Martius (Arecaceae) em uma Floresta Ombrófila Densa Montana, em Blumenau (SC). Sellowia, n.45-48, p.13-45, 1996.

REIS, M.S. dos. Distribuição e dinâmica da variabilidade genética em populações naturais de palmiteiro (Euterpe edulis Martius). Piracicaba, 1996. 210p. Tese (Doutorado) - Escola Superior de Agricultura "Luiz de Queiroz", Universidade de São Paulo.

REIS, M.S.; NODARI, R.O.; GUERRA, M.P.; et al. Na alternative in situ conservation of the Tropical Atlantic Forest. In: FOREST 94 - SIMPÓSIO INTERNACIONAL DE ESTUDOS AMBIENTAIS SOBRE ECOSSISTEMAS FLORESTAIS, 3. Porto Alegre, 1994. Anais. Porto Alegre: 1994. p.4-5.

RIBEIRO, A.S. Estrutura e dinâmica de uma população de bussu - Manicaria martiana Burret (Arecaceae), em floresta úmida de terra firma na Amazônia Central, Manaus, Brasil. Manaus, 1991. 83p. Dissertação (M.S.) - Instituto Nacional de Pesquisas Agropecuária.

RITLAND, K.; JAIN, S. A model for the estimation of outcrossing rate and gene frequencies usingn independent loci. Heredity, v.47, n.1, p.35-52. 1981.

RITLAND, K.; EL-KASSABY, Y.A. The nature of inbreeding in a seed orchard of Douglas fir as show by an efficient multilocus model. Theoretical and Appleid Genetics, v.71, p.375-384. 1985.

RITLAND, K. A series of FORTRAN computer programs for estimating plant mating systems. Journal of Heredity, v.81, 235-237p, 1990.

ROGEZ, H. Açaí: preparo, composição e melhoramento da conservação. Belém: EDUFPA, 2000. 313p.

SANTOS, J.D. dos. Estudos ecológicos e genéticos numa paisagem fragmentada visando sua conectividade, no Pontal do Paranapanema -SP. Piracicaba, 2002. 101p. 
Dissertação (Mestrado) - Escola Superior de Agricultura "Luiz de Queiroz", Universidade de São Paulo.

SARUKÁN, J; MARTINEZ-RAMOS, M.; PIÑERO, D. The analysis of demographie variability at the individual level and its populational consequences. In: DIRZO, R.; SARUKÁN, J. (Ed.). Perspectives on plant population ecology. Massachusetts: Sinawer Ass. ociats. 1984. p.83-106.

SILVA, D.M. Estrutura de tamanho e padrão espacial de uma população de Euterpe edulis Mart. (Arecaceae) em mata mesófila semidecidual no Município de Campinas, SP. Campinas, 1991. 146p.Dissertação (M.S.) - Instituto de Biologia, Universidade Estadual de Campinas.

SILVA, R.M. Sistema reprodutivo, fluxo gênico e paternidade em roça de etnovariedades de mandioca (Manihot esculenta Crantz). Piracicaba, 2000.359p. Tese (Doutorado) Escola Superior de Agricultura "Luiz de Queiroz", Universidade de São Paulo.

SILVA, R.M.; REYES, A.E.L. PATER (Program Paternity). Programa distribuido gratuitamente pelos autores na internet, na Home Page http//www.ciagri.usp.br/paterprog/, 2002.

SMITH, D.N.; DEVERY, M.E. Occurrence and inheritance of microsatellites in Pinus radiata. Genome, v.37, p.977-983, 1994.

SOLBRIG, O.T. Studies on the population biology of the genus Virola. II. The effect of plant size on fitness in Virola sororia. Evolution, v. 35, p.1080-1093, 1981.

SOUZA, L.M.F.I. de. Estrutura genética de populações naturais de Chorisia speciosa St. Hil. (Bombacaceae) em fragmentos florestais na região de Bauru (SP) - Brasil. Piracicaba, 1997. 76p. Dissertação (Mestrado) - Escola Superior de Agricultura "Luiz de Queiroz", Universidade de São Paulo.

SUPERINTENDENCIA DE DESENVOLVIMENTO DA AMAZÔNIA. Atlas climatológico da Amazônia. Belém: SUDAM, Projeto de Hidrologia e Climatologia da Amazônia, 1984. 125p.

SWAINE, M.D.; LIEBERMAN, D.; PUTZ, F.E. The dynamics of tree population in tropical forest: a review. Journal of Tropical Ecology 3: 359-366. 11987. 
TOMLINSON, P. B. The structural biology of palms. Oxford: Claredon Press, 1990. $477 \mathrm{p}$.

TONETTI, E. L. Estrutura da população, crescimento e dinâmica do banco de plântulas e fenologia reprodutiva de Euterpe edulis Mart. (Arecaceae) num trecho da floresta ombrófila densa das terras baixas do município de Paranaguá, PR. Paraná, 1997. 63p. Dissertação (M.S.) - Universidade Federal do Paraná.

VENCOVSKY, R. Análise de variância de frequências alélicas. Revista Brasileira de Genética. v.15, n.1, p.53-60, 1992.

WHITE, G.; POWELL, W. Isolation and characterization of microsatellite loci in Swietenia humilis (Meliaceae): an endangered tropical hardwood species. Molecular Ecology, v.6, p.851-860, 1997.

WEINER, J.; SOLBRIG, O.T. The meaning and measurement of size hierarchies in plant populations. Oecologia, v.61, p.334-336, 1984.

WEIR, B.S. Genetic data analysis: methods for discrete population genetic data. Sunderland: Sinauer Associates, 1990.377p.

WEIR, B.S. Genetic data analysis II: methods for discrete population genetic data. Sunderland: Sinauer Associates, 1996. 445p.

WHITMORE, T.C. Gape size and species richness in tropical rain forests. Biotropica, v. 16, p.239, 1984. 